\title{
Productiviteit, beloning en arbeidsparticipatie van ouderen
}

Citation for published version (APA):

Borghans, L., Cörvers, F., Kriechel, B., \& Montizaan, R. M. (2007). Productiviteit, beloning en arbeidsparticipatie van ouderen. Researchcentrum voor Onderwijs en Arbeidsmarkt, Faculteit der Economische Wetenschappen. ROA Reports No. 5 https://doi.org/10.26481/umarep.2007005

Document status and date:

Published: 01/01/2007

DOI:

10.26481/umarep.2007005

Document Version:

Publisher's PDF, also known as Version of record

\section{Please check the document version of this publication:}

- A submitted manuscript is the version of the article upon submission and before peer-review. There can be important differences between the submitted version and the official published version of record.

People interested in the research are advised to contact the author for the final version of the publication, or visit the DOI to the publisher's website.

- The final author version and the galley proof are versions of the publication after peer review.

- The final published version features the final layout of the paper including the volume, issue and page numbers.

Link to publication

\footnotetext{
General rights rights.

- You may freely distribute the URL identifying the publication in the public portal. please follow below link for the End User Agreement:

www.umlib.nl/taverne-license

Take down policy

If you believe that this document breaches copyright please contact us at:

repository@maastrichtuniversity.nl

providing details and we will investigate your claim.
}

Copyright and moral rights for the publications made accessible in the public portal are retained by the authors and/or other copyright owners and it is a condition of accessing publications that users recognise and abide by the legal requirements associated with these

- Users may download and print one copy of any publication from the public portal for the purpose of private study or research.

- You may not further distribute the material or use it for any profit-making activity or commercial gain

If the publication is distributed under the terms of Article $25 \mathrm{fa}$ of the Dutch Copyright Act, indicated by the "Taverne" license above, 


\title{
Productiviteit, beloning en arbeidsparticipatie van ouderen
}

\author{
L. Borghans \\ F. Cörvers \\ B. Kriechel \\ R. Montizaan
}

ROA-R-2007/5 


\section{Colofon}

(C) Researchcentrum voor Onderwijs en Arbeidsmarkt (ROA). Niets uit deze uitgave mag op enige manier worden verveelvoudigd zonder voorafgaande schriftelijke toestemming van de directeur van het ROA.

\section{Researchcentrum voor Onderwijs en Arbeidsmarkt}

Faculteit der Economische Wetenschappen en Bedrijfskunde

Universiteit Maastricht

\section{Vormgeving}

ROA secretariaat, Maastricht

\section{Verkoop}

Researchcentrum voor Onderwijs en Arbeidsmarkt

email: secretary@roa.unimaas.nl

website: www.roa.unimaas.nl

ISBN: 978-90-532I-462-6 


\section{Inhoud}

Voorwoord $\quad$ v

1 Inleiding 1

2 Literatuuroverzicht 5

2.1 Inleiding 5

2.2 Impliciete contracten en beloning van ouderen 6

$\begin{array}{lr}2.3 \text { Depreciatie van menselijk kapitaal } & 10\end{array}$

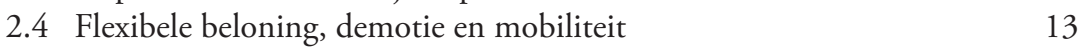

3 Data 19

3.1 Inleiding 19

$\begin{array}{ll}3.2 \text { Databronnen } & 19\end{array}$

$\begin{array}{lll}3.3 \text { Lonen } & 21\end{array}$

$\begin{array}{lll}3.4 \text { Mobiliteit } & 24\end{array}$

$\begin{array}{ll}3.5 & \text { Mobiliteit en lonen } \\ \end{array}$

4 Analyses $\quad 35$

4.1 Inleiding 35

$\begin{array}{lll}4.2 & \text { Loonvergelijking } & 35\end{array}$

$\begin{array}{ll}4.3 \text { Analyse van de residuen } & 37\end{array}$

$\begin{array}{lll}4.4 & \text { Typeringen van bedrijven } & 39\end{array}$

4.5 Relatie tussen uitstroom en beloningssystematiek van bedrijven 41

5 Conclusies $\quad 51$

$\begin{array}{lr}\text { Literatuur } & 57\end{array}$

$\begin{array}{ll}\text { Bijlage A } & 63\end{array}$ 



\section{Voorwoord}

Het voorliggende onderzoek is gefinancierd door het Ministerie van Economische Zaken, DG Economische Politiek. De auteurs willen de leden van de klankbordgroep bedanken voor hun enthousiaste en waardevolle inbreng bij de bespreking van het rapport.

De klankbordgroep bestond uit: drs. R. Leering en drs. S. Ederveen namens het Ministerie van Economische Zaken, dr. D. van Vuuren van het Centraal Planbureau, drs. K. van den Berg van het Ministerie van Financiën, dr. J. Jansen en drs. L. Janssens van het Ministerie van Sociale Zaken. 



\section{Inleiding}

De uitstroom van babyboomers die zich aan het voltrekken is op de arbeidsmarkten in de Westerse landen, zal de komende jaren het arbeidsaanbod flink beperken. Deze uitstroom zal naar verwachting gepaard gaan met een grote (vervangings)vraag naar arbeidskrachten doordat een groot deel van de uittredende ouderen vervangen dient te worden. De mede hierdoor verwachte schaarste aan personeel zal zich in Nederland niet voor alle sectoren van de economie in dezelfde mate laten voelen (RWI, 2005). Vooral in de sectoren overheid en onderwijs, kwartaire diensten en chemie lijkt een grote vervangingsvraag samen te gaan met grote knelpunten in de personeelsvoorziening.

Hoewel de relevantie van de vervangingsvraag voor tekorten op de arbeidsmarkt door sommigen sterk wordt betwist (bijv. Freeman, 2006), is het duidelijk dat de Westerse economieën en arbeidsmarkten op zeer uiteenlopende wijzen de grootschalige uittrede van oudere werkenden kunnen opvangen. Hierbij kan gedacht worden aan het verplaatsen en uitbesteden van productie-activiteiten naar landen waar de factor arbeid minder schaars en goedkoper is ('off-shoring' en 'outsourcing'), het versoepelen van de immigratieprocedures, en het kapitaalintensiever en met nieuwe productietechnieken produceren van goederen of verlenen van diensten waardoor de arbeidsproductiviteit verder toeneemt.

Daarnaast vinden er ook institutionele veranderingen plaats, die erop gericht zijn om de arbeidsmarktuittrede van ouderen uit te stellen. Zo worden pensioenvoorzieningen minder genereus en wordt het financieel aantrekkelijker om langer te blijven doorwerken. Zowel van overheidswege als op sector- en bedrijfsniveau worden maatregelen getroffen om ouderen langer aan het werk te houden of weer aan het werk te krijgen. Enerzijds wordt leeftijdsdiscriminatie van oudere werklozen tegengegaan, en besteedt het Centrum voor Werk en Inkomen (CWI) extra aandacht aan de bemiddeling van 45-plussers. Anderzijds worden regelingen en personeelsbeleid voor oudere werknemers flexibeler, zodat bijvoorbeeld in deeltijd werken, demotie en neerwaartse aanpassing of bevriezing van het salaris nu meer in beeld komen. Bovendien is bij bedrijfssaneringen en ontslagrondes het afspiegelingsbeginsel belangrijker dan het anciënniteitbeginsel geworden, waardoor ouderen weliswaar een grotere kans op ontslag hebben dan voorheen, maar tegelijkertijd de drempel voor werkgevers om ouderen aan te stellen kan zijn verlaagd. 
In het voorliggende rapport wordt onderzocht wat de consequenties zijn van één van de opties om de arbeidsparticipatie van ouderen te stimuleren, namelijk een meer flexibelere beloning die nauwer aansluit bij de productiviteit van ouderen. Omdat uit de literatuur naar voren lijkt te komen dat de productiviteit van werknemers over het algemeen minder hard stijgt gedurende de loopbaan dan de beloning, zijn ouderen mogelijk minder aantrekkelijk voor werkgevers dan jongeren. Het gebruik van meer flexibele beloningssystemen is de laatste jaren toegenomen, waardoor bedrijven tot op zekere hoogte de beloning kunnen aanpassen aan de productiviteit. Hoewel expliciete productiviteitscijfers op individueel niveau ontbreken, kan worden aangenomen dat bedrijven die sterker variëren in de beloning tussen medewerkers, zich wat betreft hun beloningsbeleid meer richten naar de productiviteitsverschillen tussen hun medewerkers. Dit zou de arbeidsparticipatie van oudere werknemers in deze bedrijven kunnen stimuleren.

Door te kijken naar de verschillen tussen de loongroei van individuele werknemers binnen een bedrijf en door te analyseren hoe sterk de loongroei van ouderen binnen het bedrijf is, kan de beloningssystematiek van bedrijven worden getypeerd aan de hand van het waargenomen beloningsbeleid. Vervolgens dient te worden vastgesteld op welke manier een meer gedifferentieerde loongroei tussen werknemers samenhangt met de uitstroom van ouderen, en of hun arbeidsparticipatie wordt gestimuleerd als een deel van de bedrijven de stap maakt naar een flexibelere beloning van werknemers. Voor de uitvoering van de analyses worden enkele grote administratieve databronnen van het Centraal Bureau voor de Statistiek (CBS) gebruikt.

Er zijn verschillende mechanismes die een rol spelen bij de samenhang tussen de beloning van oudere werknemers door bedrijven enerzijds, en de uitstroom en arbeidsparticipatie van ouderen anderzijds. Ten eerste, wat betreft de vraagzijde van de arbeidsmarkt kan verwacht worden dat bedrijven oudere werknemers langer in dienst willen houden als het loon van ouderen beter aansluit bij hun productiviteit. Onder de veronderstelling dat de productiviteitsontwikkeling van ouderen achterblijft bij hun loonontwikkeling, zal volgens deze redenering de uitstroom van ouder personeel lager zijn naarmate bedrijven de beloning van ouderen sterker neerwaarts aanpassen en naarmate de beloningsstructuur een grotere variatie laat zien.

Ten tweede kan wat betreft de aanbodzijde van de arbeidsmarkt verwacht worden dat ouderen eerder uitstromen van de arbeidsmarkt als de beloning minder aantrekkelijk is, omdat de alternatieve kosten van vrije tijd dalen. Dat betekent dat een hoge beloning van ouderen gepaard gaat met een lage uitstroom en een hoge arbeidsparticipatie. Onder de veronderstelling dat werknemers risico-avers zijn ten aanzien van de variatie in de beloningstructuur, worden bedrijven met veel variatie in de beloning van hun personeel geconfronteerd met een grote uitstroom van oudere werknemers naar buiten de arbeidsmarkt, of naar bedrijven die belonen op basis van anciënniteit. In tegenstelling tot de eerste redenering hangen betere beloningen en een lagere variatie nu samen met een lagere uitstroom. 
Het is van belang om op te merken dat bedrijven de beloningsstructuur weloverwogen kunnen aanpassen aan de positie van hun personeel op de arbeidsmarkt, op basis van zowel de waarde van oudere personeelsleden voor het bedrijf waar ze werkzaam zijn als de voorkeuren van deze werknemers. Bedrijven die oudere personeelsleden langer in dienst willen houden zullen de uitstroom voorkomen door hen beter te belonen dan andere bedrijven. Afhankelijk van de achtergrondkenmerken en preferenties van het personeel dat bij hen in dienst is en hun schaarste op de arbeidsmarkt, zullen bedrijven de uitstroom van het (oudere) personeel afremmen door betere beloningen te bieden. Dit laatste geldt in het bijzonder voor ouderen met een hoge productiviteit, bijvoorbeeld degenen met veel bedrijfsspecifieke kennis en vaardigheden. Op deze manier kunnen ook de (transactie)kosten van de rekrutering van potentiële kandidaten en de trainingskosten voor het nieuwe personeel binnen de perken worden gehouden.

Alleen als de vraagzijde van de arbeidsmarkt dominant is voor de relatie tussen beloningsbeleid en uitstroom van ouderen, biedt dit de mogelijkheid om door veranderingen in het beloningsbeleid bij bedrijven de uitstroom van ouderen te reduceren en hun arbeidsparticipatie te verhogen. Er dient echter ermee rekening te worden gehouden dat het beloningbeleid van bedrijven al 'optimaal' is, dat wil zeggen dat ze de aanbodzijde van de arbeidsmarkt al hebben meegenomen bij hun beslissingen over de beloning van werknemers.

In het hier voorgestelde onderzoek wordt nagegaan wat het feitelijke beloningsbeleid van bedrijven is, en hoe dit uitpakt voor de oudere werknemers. Door te analyseren in welke mate er sprake is van variatie in de beloning tussen (oudere) werknemers van verschillende bedrijven wordt een indicatie verkregen van de mate waarin bedrijven rekening houden met productiviteitsverschillen tussen (oudere) werknemers. Vervolgens wordt geanalyseerd hoe de uitstroom van ouderen en het beloningsbeleid met elkaar samenhangen. Voor de interpretatie van de uitkomsten wordt zowel naar de vraag- als de aanbodzijde van de arbeidsmarkt gekeken.

In hoofdstuk 2 wordt een overzicht gegeven van de literatuur over de verhouding tussen loon en productiviteit. Daarbij wordt ingegaan op verschillende theorieën over de discrepantie tussen loon en productiviteit bij met name ouderen. Tevens wordt een overzicht gegeven van het schaarse empirische onderzoek op dit terrein. Vervolgens wordt ingegaan op flexibele beloningssystemen en demotie, en de relatie met de arbeidsmarktpositie van ouderen.

In hoofdstuk 3 wordt een beschrijving gegeven van de ontwikkelingen in de beloning en mobiliteit van werknemers op basis van de verschillende gekoppelde bestanden in het Sociaal Statistisch Bestand (SSB) van het CBS. De gekoppelde bestanden betreffen de Gemeentelijke Basisadministratie (GBA), de administratieve databestanden van de verzekeringsbank en de belastingdienst, en de Enquête Werkgelegenheid en Lonen (EWL) van het CBS. 
In hoofdstuk 4 worden de loonvergelijkingen geschat van alle bedrijven en organisaties in de EWL met meer dan Io werknemers voor de periode van 1999 tot 2004. De bedrijven worden getypeerd door drie kenmerken uit de regressievergelijking voor de loongroei: de gemiddelde loongroei per bedrijf, de leeftijdsafhankelijke loongroei en de onverklaarde variantie. Het laatste kenmerk kan als maatstaf gelden voor de vrijheid van bedrijven om te variëren in beloning tussen individuen. Vervolgens wordt er gekeken naar de relatie tussen de drie genoemde kenmerken en de mobiliteit van werknemers. Daarbij wordt tevens een vergelijking gemaakt tussen de oudere en de jongere werknemersgroepen.

Tot slot volgen in hoofdstuk 5 de conclusies. 


\section{Literatuuroverzicht}

\section{$2.1 \quad$ Inleiding}

In het licht van de vergrijzing en de toenemende krapte op de arbeidsmarkt zou het aantrekkelijk moeten zijn voor bedrijven om oudere werknemers in dienst te houden. In de praktijk blijkt echter dat ouderen een relatief grote kans op langdurige werkloosheid hebben en dat de participatiegraad onder personen van 45 jaar en ouder vrij laag is. Werkgevers lijken geneigd te zijn om vooral oudere werknemers af te laten vloeien bij bedrijfssaneringen of reorganisaties. Daarnaast zijn werkgevers minder geneigd om ouderen in dienst te nemen. Een mogelijke factor die hierbij een rol speelt is dat ouderen relatief dure arbeidskrachten zijn.

In theorie zullen werknemers bij een perfect werkende arbeidsmarkt worden beloond op basis van hun marginaal product, ongeacht de fase van de levenscyclus waarin individuen zich bevinden. Loonverschillen tussen individuen gebaseerd op verschillen in scholing en ervaring worden in deze context geïnterpreteerd als productiviteitsverschillen. Echter, de praktijk wijst uit dat de beloning van werknemers niet altijd correspondeert met de productiviteitsontwikkeling over hun carrière. Zo hangt de afwijking tussen de productiviteitsontwikkeling in Nederland mogelijk samen met de in CAO's vastgelegde beloningstraditie om het salaris van werknemers te laten toenemen met het aantal dienstjaren.

De vraag is welke factoren leiden tot deze afwijking tussen beloning en productiviteit. Binnen de economische literatuur worden meerdere - vaak complementaire en niet empirisch te onderscheiden - factoren genoemd die afwijkingen tussen loon en productiviteit over de levenscyclus van werknemers bewerkstelligen. Wij onderscheiden twee stromingen binnen de economische literatuur die verschillen in beloning en productiviteit trachten te verklaren: i) impliciete contract theorie en ii) depreciatie van menselijk kapitaal.

In dit hoofdstuk zal op basis van een literatuurstudie een overzicht worden gegeven van hoe het loon en productiviteit zich verhouden over verschillende fasen in de levenscyclus. Daartoe zal de empirische literatuur, gericht op het meten van loonprofielen en productiviteit, worden besproken en wordt ingegaan op twee factoren die 
worden genoemd als verklaring voor afwijkingen in de loon- en productiviteitstructuur over de levenscyclus van werknemers. Ten eerste wordt in de volgende paragraaf ingegaan op de rol van impliciete contracten. Ten tweede wordt in paragraaf 2.3 de invloed van depreciatie van menselijk kapitaal en technologische veranderingen op de arbeidsmarktpositie van oudere werknemers besproken. In de laatste paragraaf wordt ingegaan op twee mogelijkheden die bestaande beloningstradities doorbreken en de arbeidsmarktpositie van ouderen kunnen verbeteren, namelijk flexibele beloning en demotie. Er wordt nagegaan in hoeverre deze reeds worden toegepast, en er wordt gekeken naar de gevolgen ervan voor de arbeidsmarktpositie van ouderen.

\subsection{Impliciete contracten en beloning van ouderen}

Empirische studies over de verhouding tussen loon en productiviteit over de levenscyclus zijn schaars, aangezien productiviteit vaak niet geobserveerd wordt. Tevens, als productiviteit daadwerkelijk wordt gemeten, dan zijn de desbetreffende maatstaven vaak van toepassing op specifieke beroepen of sectoren. Derhalve hebben de meeste studies zich gericht op het analyseren van hoe loonprofielen zich ontwikkelen over de levenscyclus (zie o.a. de studies van Topel, I99I; Neumark en Taubman, 1995). Desondanks bestaan er enkele studies die zowel het verloop van loonprofielen als productiviteitsontwikkeling hebben geanalyseerd. Deze zijn weergegeven in Tabel 2.I. Kenmerkend voor deze studies is dat zij voornamelijk gebruik maken van bedrijfsspecifieke data, met als nadeel dat de resultaten moeilijk zijn te generaliseren. Tot nu toe heeft geen enkele studie voor Nederland gekeken naar de verschillen tussen bedrijven in hun beloningssystematiek van oudere en jongere werknemers.

Een eerste relevante bijdrage is geleverd door Medoff en Abraham (I98I) die microdata voor een bedrijf uit de Verenigde Staten hebben gebruikt voor het analyseren van beloning en productiviteit. De door de hun gebruikte data bevat zowel administratieve gegevens over werknemers als een beoordeling van de productiviteit van werknemers door hun directe leidinggevenden. Het belangrijkste resultaat van de studie van Medoff en Abraham (I98I) is dat productiviteit maar een beperkte rol heeft bij het verklaren van de loonprofielen van werknemers. De beloning van werknemers neemt toe met contractduur, terwijl hun productiviteit niet verandert. Dit impliceert dat werknemers meer dan hun productiviteit verdienen op oudere leeftijd. Dit resultaat staat niet op zichzelf, maar wordt ook gevonden door latere studies. Onder andere studies van Kotlikoff en Gokhale (1992) voor werknemers in een industrieel bedrijf in de Verenigde Staten, en Dostie (2006), op basis van matched werknemers-werkgeversdata voor Canada, vinden eveneens dat oudere werknemers meer verdienen dan de waarde van hun marginale productiviteit. ${ }^{1}$

I. Echter niet alle studies vinden een productiviteit-loon gat voor oudere werknemers. De studies van Hellerstein en Neumark (1995) en Hellerstein e.a. (1999) vinden dat beloning en productiviteit positief gecorreleerd zijn over de levenscyclus. Echter de resultaten in beide studies zijn beperkt robuust en zijn zeer gevoelig voor meetfouten. 
Tabel 2.1

Empirische studies over productiviteit en beloning

\begin{tabular}{|c|c|c|c|c|}
\hline Ateurs & Analyse en data & Periode & Land & Uitkomsten \\
\hline $\begin{array}{l}\text { Medoff en } \\
\text { Abraham (1981) }\end{array}$ & $\begin{array}{l}\text { Analyse van beloning en productiviteit } \\
\text { op basis van administratieve gegevens } \\
\text { en beoordeling van productiviteit van } \\
\text { werknemers in een groot industrieel } \\
\text { bedrijf }\end{array}$ & 1973-1976 & VS & $\begin{array}{l}\text { Werknemers verdienen meer naarmate } \\
\text { zij ouder worden terwijl op basis van de } \\
\text { beoordeling van de productiviteit door } \\
\text { werkgevers niet blijkt dat zij productiever } \\
\text { worden. }\end{array}$ \\
\hline $\begin{array}{l}\text { Kotlikoff en } \\
\text { Gokhale (1993) }\end{array}$ & $\begin{array}{l}\text { Analyse van leeftijd-productiviteit } \\
\text { profielen m.b.v. data voor de verwachte } \\
\text { waarde van inkomens van nieuwe } \\
\text { werknemers ( } 300.000 \text { werknemers) } \\
\text { van een Fortune } 1000 \text { bedrijf. Er } \\
\text { wordt gebruik gemaakt van annual } \\
\text { survical hazards en gereduceerde } \\
\text { vormvergelijkingen. }\end{array}$ & 1968-1983 & VS & $\begin{array}{l}\text { Productiviteit neemt af met leeftijd, } \\
\text { zodat lonen uiteindelijk hoger zijn dan de } \\
\text { waarde van de marginale productiviteit }\end{array}$ \\
\hline Dostie (2006) & $\begin{array}{l}\text { Analyse van afwijkingen in } \\
\text { productiviteit en beloning op basis van } \\
\text { Canadese werkgevers-werknemers data } \\
\text { (Workplace and Employee Survey). }\end{array}$ & $1999-2003$ & Canada & $\begin{array}{l}\text { Er worden concave leeftijd- } \\
\text { loonvergelijkingen en leeftijd- } \\
\text { productiviteitprofielen gevonden. Voor } \\
\text { laagopgeleide werknemers geldt dat } \\
\text { productiviteit lager is dan het loon na een } \\
\text { leeftijd van } 55 \text { jaar. }\end{array}$ \\
\hline
\end{tabular}

Een verklaring voor deze afwijking in beloning en productiviteit over de levenscyclus wordt gegeven door de impliciete contract theorie. Impliciete contract theorie is gericht op het verklaren van impliciete contracten om stabiele lange-termijn arbeidsrelaties te bewerkstelligen. Kenmerkend van deze lange-termijn contracten is dat zowel de werkgever als de werknemer ermee hebben ingestemd om een deel van de beloning uit te stellen naar het einde van het contract (oplopende loonprofielen), zodat een langetermijnarbeidsrelatie tot stand komt. Dit betekent dat jonge werknemers minder verdienen dan de waarde van hun marginale productiviteit, terwijl oudere werknemers meer verdienen dan de waarde van hun marginale productiviteit. ${ }^{2}$

De vier belangrijkste redenen voor het afsluiten van impliciete contracten zijn (zie Blinder, 1982):

- Hoge transactiekosten als gevolg van recruitment en sollicitatieprocedures stimuleert bedrijven om de mobiliteit in hun werknemersbestand te verkleinen

- Bedrijven kunnen vaak moeilijk de kenmerken van individuen bepalen die (nog) niet werkzaam zijn bij hun bedrijf. Aangezien werkgevers hun eigen werknemers beter kennen, zullen zij hun huidige productieve werknemers willen handhaven.

- Bedrijven investeren in hun werknemers door hen bedrijfsspecifieke training te laten volgen en willen blijven profiteren van de hogere productiviteit van

2. Voor evenwicht moeten de verdisconteerde onderbetaling op jonge leeftijd gelijk zijn aan de verdisconteerde overbetaling op oudere leeftijd. 
hun werknemers. Daartoe willen bedrijven de mobiliteit van hun werknemers met bedrijfsspecifieke vaardigheden beperken.

- Bedrijven willen de motivatie en productiviteit van hun werknemers stimuleren. Door werknemers oplopende loonprofielen in het vooruitzicht te stellen, zijn deze bereid zich extra in te spannen, of in elk geval zich niet te drukken.

De eerste drie genoemde factoren hebben gemeen dat impliciete contracten worden afgesloten met als primair doel het verlagen van de mobiliteit van het werknemersbestand. Hoge transactiekosten bij sollicitatieprocedures en vertrek van werknemers, onzekerheid bij het analyseren van vaardigheden en bekwaamheid van individuen buiten de organisatie en bedrijfsspecifieke investeringen waarbij bedrijven participeren in de kosten, zullen leiden tot de wens van bedrijven om de mobiliteit van hun werknemersbestand beperkt te houden. Dit kunnen bedrijven bewerkstelligen door oplopende loonprofielen aan te bieden. Werknemers zullen door de uitgestelde loonbetalingen gemotiveerd worden om langer door te werken bij hetzelfde bedrijf. Immers, oudere werknemers, met een impliciet arbeidscontract waarin oplopende loonprofielen zijn opgenomen, verdienen meer dan de waarde van hun productiviteit en dus ook meer dan het marktloon. Daardoor zullen deze werknemers minder geneigd zijn om hun huidige werkgever voortijdig te verlaten, aangezien zij dan hun rechten op de hoge beloning aan het einde van hun carrière verspelen en terugvallen op het marktloon. De lage mobiliteit van het werknemersbestand leidt vervolgens tot lage transactiekosten en hogere opbrengsten van bedrijfsspecifieke investeringen. De werknemer en de werkgever zullen samen tot een optimale verdeling dienen te komen van deze extra opbrengsten, zodat beide partijen een voordeel hebben van de oplopende loonprofielen.

De rol van oplopende profielen bij het beperken van mobiliteit is in de empirische literatuur uitgebreid besproken. Een belangrijke reden voor het beperken van de arbeidsmobiliteit is gelegen in de hoge transactiekosten als gevolg van werving en selectie. Vooral voor de Verenigde Staten wordt gevonden dat oplopende profielen als instrument worden gebruikt voor het beperken van de arbeidsmarktmobiliteit (Prendergast, 1999; Cahuc en Zylberberg, 2004, hoofdstuk 6). Johnson (I996) toont aan dat werkgevers vooral geneigd zijn om oplopende loonprofielen aan te bieden als zij moeite hebben om de kenmerken van potentiële nieuwe werknemers te beoordelen en daarom de voorkeur geven aan het handhaven van de meest productieve werknemers van hun personeelsbestand. Montizaan e.a. (2007) vinden, op basis van de National Longitudinal Survey for Older Men voor de Verenigde Staten, dat bedrijfsspecifieke investeringen in menselijk kapitaal gecorreleerd zijn met sterker oplopende loonprofielen en een lagere mobiliteit dan bij generieke investeringen.

Voor Nederland hebben Groot en Verberne (1997) geanalyseerd hoe mobiliteit, personeelsverloop en financiële motieven (reserveringsloon) aan elkaar zijn gerelateerd. Op basis van het OSA Aanbod-panel (1985-I986), vinden zij dat een lagere mobiliteit simultaan wordt veroorzaakt door dalende financiële voordelen van baanveran- 
deringen en hogere kosten van mobiliteit. ${ }^{3}$ Echter in tegenstelling tot de Verenigde Staten, worden in Nederland impliciete contracten institutioneel bepaald op collectief niveau. Op dit ogenblik zijn het voornamelijk de sociale partners die bij CAO-onderhandelingen tot overeenkomsten komen die door individuele werkgevers en werknemers als leidraad worden gebruikt voor het opstellen van het arbeidscontract op individueel niveau.

In tegenstelling tot de eerste drie factoren, heeft de vierde verklarende factor voor het afsluiten van impliciete contracten met oplopende loonprofielen betrekking op het stimuleren van de productiviteit over de gehele levenscyclus. Lazear (1979) toont in een invloedrijke studie aan dat in een situatie waarin bedrijven de productiviteit van hun werknemers moeilijk kunnen vaststellen, het voordelig kan zijn voor zowel werknemer als werkgever om oplopende loonprofielen te introduceren. De grondgedachte van het model van Lazear (1979) is dat werknemers zich kunnen onttrekken aan hun werk doordat werkgevers hun productiviteit maar in beperkte mate kunnen meten. Werknemers kunnen hierdoor geneigd zijn om zich minder in te spannen. De kosten voor het bedrijf zijn dan dat de productiviteit lager is dan de potentiële productiviteit. Anderzijds, de potentiële kosten voor werknemers van 'slecht gedrag' hangt af van de kans dat men wordt betrapt op het leveren van suboptimale inspanningen of prestaties en de hoogte van de 'straf' die daar op volgt. Doorgaans zal de straf bestaan uit het niet verlengen van het arbeidscontract of ontslag.

De herverdeling van beloning over de levenscyclus door het hanteren van oplopende loonprofielen kan in deze context de mate van slecht gedrag beperken. Als werknemers verdienen naar de waarde van hun marginale productiviteit, zullen zij indifferent zijn ten opzichte van handhaving van hun huidige arbeidsrelatie. Daarentegen, bij oplopende loonprofielen zullen werknemers op oudere leeftijd meer verdienen dan de waarde van hun marginale productiviteit. Het ontbinden van het arbeidscontract met hun huidige werkgever zal dan leiden tot een lager loon op latere leeftijd. De oplopende profielen bewerkstelligen derhalve een directe stijging van de kosten van ontslag, waardoor werknemers minder geneigd zullen zijn om slecht gedrag te vertonen, zeker naarmate de arbeidsmarktrelatie vordert. Het gevolg is dat werknemers over de gehele levenscyclus productiever zijn dan in een situatie zonder oplopende loonprofielen, met als gevolg dat zowel winstmarges voor bedrijven als de beloning voor de werknemers hoger zijn. ${ }^{4}$

De empirische literatuur die het model van Lazear (1979) als uitgangspunt neemt, makkt in essentie gebruik van de aanname dat oplopende profielen vooral worden verstrekt in situaties waarin de productiviteit moeilijk meetbaar is. Dit wordt duide-

3. Kosten van mobiliteit worden eenmalig gemeten nadat men van baan is veranderd. Kosten van mobiliteit bestaan uit zowel financiële (transactiekosten) als psychologische kosten (verlaten van vertrouwde omgeving etc.).

4. De mate waarin bedrijven en hun werknemers profiteren van de hogere productiviteit hangt af van de arbeidsmarktpositie van beide partijen. 
lijk uit Tabel 2.2, waarin een overzicht van de empirische studies over oplopende loonprofielen en productiviteit is gegeven. Zo hebben Lazear en Moore (1984) de loonprofielen vergeleken tussen zelfstandigen en werknemers, waarbij zij ervan uit gaan dat zelfstandigen geen reden hebben om minder hard te werken. Consistent met de theorie, vinden zij dat loonprofielen steiler zijn voor werknemers dan voor zelfstandigen. Hutchens (1984) heeft Lazears's theorie getest, gebruikmakend van de National Longitudinal Survey of Older Men en de Dictionary of Occupational Titles, door werknemers met eenvoudig te monitoren banen te vergelijken met andere werknemers. Eenzelfde studie is uitgevoerd door Bayo-Moriones e.a. (2004) die met industriële fabrieksdata voor Spanje specifiek aandacht besteden aan de relatie tussen senioriteitbetalingen en monitoring. Zowel Hutchens (1984) als Bayo-Moriones e.a. (2004) vinden dat oplopende loonprofielen dienen als substituut voor monitoring.

Tabel 2.2

Empirische studies over productiviteit en oplopende loonprofielen

\begin{tabular}{|c|c|c|c|c|}
\hline Ateurs & Analyse en data & Periode & Land & Uitkomsten \\
\hline Lazear (1979) & $\begin{array}{l}\text { Analyse van kans op verplichte } \\
\text { pensioenclausules in arbeidscontracten } \\
\text { m.b.v. US Longitudinal Retirement History } \\
\text { Survey }\end{array}$ & 1969-1971 & VS & $\begin{array}{l}\text { Contractduur en loongroei hebben invloed } \\
\text { op de kans van verplichte pensionering. } \\
\text { Correlatie tussen verplichte pensionering } \\
\text { en pensioensysteem is groot }\end{array}$ \\
\hline $\begin{array}{l}\text { Lazear en Moore } \\
\text { (1984) }\end{array}$ & $\begin{array}{l}\text { Analyseren of werknemers steilere } \\
\text { loonprofielen hebben dan zelfstandigen } \\
\text { (OLS modellen) m.b.v. National } \\
\text { Longitudinal Survey }\end{array}$ & 1978 & vs & $\begin{array}{l}\text { Werknemers hebben steilere loonprofielen } \\
\text { dan zelfstandigen }\end{array}$ \\
\hline Hutchens (1987) & $\begin{array}{l}\text { Analyseren of werknemers met zich vaak } \\
\text { herhalende taken worden gekenmerkt } \\
\text { door absentie van pensioenen, verplichte } \\
\text { pensionering, kortere contractduur en } \\
\text { hogere lonen van oudere werknemers } \\
\text { (Probit en OLS-modellen ) Data: National } \\
\text { Longitudinal Survey }\end{array}$ & 1971 & vS & $\begin{array}{l}\text { Resultaten zijn consistent met de theorie } \\
\text { van Lazear (1979) }\end{array}$ \\
\hline $\begin{array}{l}\text { Bayo-Moriones } \\
\text { (2006) }\end{array}$ & $\begin{array}{l}\text { Analyse van relatie tussen } \\
\text { senioriteitsbetalingen en monitoring m.b.v } \\
\text { van data voor } 734 \text { Spaanse industriële } \\
\text { bedrijven. Gebruik van Probit and Ordered } \\
\text { Probit modellen }\end{array}$ & 1997 & Spanje & $\begin{array}{l}\text { Resultaten zijn consistent met de theorie } \\
\text { van Lazear (1979) }\end{array}$ \\
\hline
\end{tabular}

\subsection{Depreciatie van menselijk kapitaal}

In impliciete contract theorie komt de afwijking tussen beloning en productiviteit tot stand door het beloningssysteem van bedrijven dat dient als beleidsinstrument ter stimulering van een lage mobiliteit of verhoging van productiviteit van werknemers over de levenscyclus. Echter een productiviteit-loon-gat voor oudere werknemers kan eveneens bewerkstelligd worden door een ongeanticipeerde depreciatie van de waarde van menselijk kapitaal (productiviteit), in de context van neerwaartse loonrigiditeit en een goede ontslagbescherming. In dat geval zullen werkgevers initiatieven ontwik- 
kelen gericht op vervroegde uittrede, verlaging van de beloning van oudere werknemers of investeringen in menselijk kapitaal (Aghion e.a., 2000; Aubert e.a., 2006).

Er kunnen twee vormen van depreciatie van menselijk kapitaal worden onderscheiden (De Grip en Van Loo, 2002): i) technische depreciatie en ii) economische depreciatie. Technische depreciatie refereert aan verlies van vaardigheden of capaciteiten van werknemers, terwijl economische depreciatie refereert aan verlies van de waarde van menselijk kapitaal. Technische depreciatie kan ontstaan als gevolg van slijtage door het natuurlijk verouderingsproces of atrofie door onvoldoende gebruik van vaardigheden. Daarmee is technische depreciatie vaak een geleidelijk proces waarop werkgever en werknemer kunnen anticiperen. Daarentegen is economische depreciatie het gevolg van baanspecifieke depreciatie door technologische en organisatieverandering, die vaak schoksgewijs optreedt. Derhalve zal voornamelijk economische depreciatie resulteren in loon-productiviteit divergenties waarop werknemer en werkgever slechts in beperkte mate op hebben kunnen anticiperen. ${ }^{5}$

Uit de literatuur over het effect van technologische verandering komt naar voren dat economische depreciatie leidt tot een verslechtering van de arbeidsmarktpositie van ouderen (e.g. Zeckhauser, I968; Aghion e.a., 2000). Technologische verandering leidt tot veranderingen in de vraag naar vaardigheden. Terwijl oudere werknemers over vaardigheden beschikken die relevant zijn voor de oude technologie, hebben jongere werknemers tijdens hun opleiding vaak leren werken met de nieuwste technologieën.

Doordat vaardigheden vaak moeilijk overdraagbaar zijn tussen technologieën, zal de waarde van menselijk kapitaal van oudere werknemers meer afnemen ten opzichte van dat van jongere werknemers. Daarnaast zullen werkgevers ook minder snel geneigd zijn om te investeren in oudere werknemers om een mogelijk productiviteit-loon gat te dichten, aangezien de terugverdientijd voor investeringen in oudere werknemers korter is en oudere werknemers meer moeite hebben om nieuwe vaardigheden op te doen (Aubert e.a., 2006).

Voor Nederland tonen Gelderblom e.a. (2003) op basis van het OSA-vraagpanel van $200 \mathrm{I}$ aan dat de mate van vergrijzing van het arbeidsbestand van bedrijven negatief is gecorreleerd met de bedrijfsprestaties terwijl bedrijven met een ouder personeelsbestand hogere loonkosten hebben. Problematisch is echter dat productiviteit wordt gemeten als toegevoegde waarde per werknemer, zodat zij geen beeld kunnen krijgen van de productiviteit van individuele werknemers. Wel vinden Gelderblom e.a. (2003) dat bedrijven met een ouder personeelsbestand gemiddeld achter lopen

5. Bartel en Sicherman (1993) tonen aan dat de effecten van graduele technologische veranderingen en technologische schokken op de arbeidsmarktpositie van oudere werknemers sterk verschilt. Voornamelijk schokken leiden tot een verslechtering van de arbeidsmarktpositie van ouderen, aangezien zij hierop niet konden participeren. 
op technologisch gebied. Dit kan duiden op mogelijke negatieve effecten van depreciatie van menselijk kapitaal, waardoor een bedrijf zich minder goed kan aanpassen aan nieuwe technologieën. Dit laatste suggereert dat oudere werknemers een zwakke arbeidsmarktpositie hebben door technologische verandering

De mate van economische depreciatie en de effecten daarvan kunnen echter sterk verschillen voor specifieke groepen werknemers. Zo tonen meerdere studies aan dat technologische verandering de arbeidsmarktpositie van hoog opgeleide werknemers positief beïnvloedt, terwijl die van laagopgeleide werknemers wordt geschaad. Loonverschillen naar opleidingsniveau zijn sinds de jaren 8 o sterk toegenomen, waarbij de loongroei voor oudere laagopgeleide ouderen achterblijft (e.g. Katz en Murphy, I992; Autor e.a., I998; Allen, 200I). Echter, niet alleen opleidingsniveau is bepalend voor de mate waarin een werknemer vaardigheden bezit die noodzakelijk zijn voor het hanteren van nieuwe technologieën. Ook werkervaring kan bijdragen aan het aanpassingsvermogen van werknemers. Bijvoorbeeld Weinberg (2002) toont aan, met behulp van de Current Population Survey voor de Verenigde Staten, dat als oude en nieuwe technologieën (computergebruik) complementair zijn, de arbeidsmarktpositie van werknemers met meer werkervaring kan verbeteren. De arbeidsmarktpositie van specifieke groepen (laagopgeleiden met veel werkervaring) oudere werknemers kan derhalve zelfs verbeteren als gevolg van technologische verandering.

Werkervaring heeft echter alleen een positieve invloed op adoptie van nieuwe technologieën als werknemers niet 'vastroesten' in hun functie (atrofie) en flexibel blijven. Het is van vitaal belang dat werkgevers en werknemers aandacht besteden aan de inzetbaarheid van hun personeel (Van Loo e.a., 2005). Plezier houden in het werk, werknemers actief houden door onder andere het hanteren van taakroulatie en het investeren in het kennisniveau van werknemers zijn relevante factoren die bijdragen aan de inzetbaarheid van oudere werknemers. Uit een studie van Song (2005) naar de relatie tussen technologische verandering, training en de arbeidsmarktpositie van werknemers, blijkt dat vooral werknemers met bedrijfsspecifiek kapitaal gevoelig zijn voor atrofie en gekenmerkt worden door een beperkte inzetbaarheid, zeker ten opzichte van werknemers met generiek menselijk kapitaal. Daardoor heeft technologische verandering voornamelijk een negatief effect op de arbeidsmarktpositie van ouderen met bedrijfsspecifiek menselijk kapitaal, terwijl de arbeidsmarktpositie van werknemers met generiek menselijk kapitaal positief wordt beïnvloed. Een andere studie van Gould (2005) komt tot hetzelfde resultaat en vindt dat technologische verandering leidt tot een toename in de vraag naar generieke vaardigheden.

Schoksgewijze technologische verandering lijkt dus over het algemeen te leiden tot een verslechtering van de arbeidsmarktpositie van ouderen. Echter, onder bepaalde omstandigheden kan het echter leiden tot verbetering van de arbeidsmarktpositie van ouderen, vooral als nieuwe technologieën complementair zijn met de oude. Hoe technologische schokken de arbeidsmarktpositie van oudere werknemers beïnvloeden 
hangt samen met het personeelsbeleid van werkgevers, het opleidingsniveau, de werkervaring en het soort menselijk kapitaal dat werknemers bezitten.

\subsection{Flexibele beloning, demotie en mobiliteit}

In het geval dat technologische schokken leiden tot een verlaagde productiviteit van ouderen, zullen werkgevers initiatieven ontwikkelen om deze groep werknemers vervroegd te laten uittreden, of zullen zij trachten de productiviteit meer in overstemming te brengen met de relatief hoge beloning van ouderen. Dat kan door meer in de kennis en vaardigheden van oudere werknemers te investeren. Een andere mogelijkheid, die hier centraal staat, is dat werkgevers hun oudere werknemers in dienst houden door de beloning meer in overstemming te brengen met de productiviteit. ${ }^{6}$ Dat kan door i) een flexibel beloningssysteem zoals prestatiebeloning te hanteren, of door ii) demotie. Beide mogelijkheden worden hieronder achtereenvolgens besproken.

\section{Prestatiebeloning}

Uit Borghans en Kriechel (2006a) blijkt dat in 200 o ongeveer I0,I\% van de bedrijven in Nederland prestatiebeloning op basis van objectieve criteria kende, en $16,0 \%$ op basis van subjectieve beoordelingen. Ondanks dat de definitie van prestatiebeloning niet eenduidig is, kan worden vastgesteld dat het gebruik van flexibele beloningssystemen gedurende de laatste jaren is toegenomen in Nederland. Gielen e.a. (2006) hebben op basis van het OSA-arbeidsvraagpanel I995-200I onderzoek gedaan naar de invoering van prestatiebeloning. Volgens deze studie paste in $199525 \%$ van de bedrijven prestatiebeloning toe, en steeg dit percentage in 200I tot 39\%. Volgens SZW (2005) is het percentage CAO's met resultaatafhankelijke beloningen gestegen van $26 \%$ in 200 I tot $37 \%$ in 2004 .

Hoewel expliciete productiviteitscijfers op individueel niveau ontbreken, wordt aangenomen dat bedrijven die sterker variëren in beloning tussen medewerkers, zich wat betreft hun beloningsbeleid meer richten naar de productiviteitsverschillen tussen hun medewerkers. Echter, daarbij geldt wel dat bedrijven prestatiebeloning maar tot op zekere hoogte kunnen toepassen, aangezien CAO-afspraken en arbeidsmarktinstituties maar een beperkte mate van beleidsdiscretie toelaten. Dit komt onder andere tot uiting in de sterke verschillen in de mate van gebruik van prestatiebeloning tussen sectoren. Terwijl prestatiebeloning relatief vaak voorkomt in de bouwsector en de

6. Bij het verstrekken van impliciete contracten zal het voor werkgevers niet lonen om oplopende loonprofielen te doorbreken zonder dat verlies aan geloofwaardigheid plaatsvindt. Werkgevers zullen hun goede reputatie op de arbeidsmarkt verliezen door jongere werknemers te belonen onder dan de waarde van hun marginale productiviteit, om vervolgens deze werknemers op latere leeftijd te ontslaan of een lagere beloning te geven dan initieel was afgesproken. Immers, voor evenwicht moet de verdisconteerde onderbetaling op jonge leeftijd gelijk zijn aan de verdisconteerde overbetaling op oudere leeftijd. Daardoor zullen bedrijven geen oplopende loonprofielen meer kunnen aanbieden met als gevolg van de productiviteit van werknemers stagneert en de arbeidsmarktmobiliteit toeneemt. 
landbouwsector, wordt in het onderwijs en de zorgsector maar in zeer beperkte mate prestatiebeloning toegepast (Gielen e.a., 2006). Daarbij speelt ook mee dat productiviteit van individuele werknemers niet in elk beroep of sector kan worden gemeten.

Gielen e.a. (2006) vinden op basis van een directe vergelijking tussen bedrijven met en zonder prestatiebeloning dat werknemers in bedrijven met prestatiebeloning productiever zijn. Dit positieve verband wordt bewerkstelligd door een hoger inspanningsniveau van werknemers als gevolg van het 'incentive effect' van prestatiebeloning, en is in overstemming met de meeste internationale studies op dit terrein (zie bijv. Prendergast, 1999; Paarsch and Shearer, 1999, 2000; Haley, 2003). Daarnaast dient prestatiebeloning (indirect) als selectiemiddel bij het aantrekken van nieuwe productievere werknemers terwijl minder productieve werknemers zullen uitstromen (zie bijv. Lazear, 2000, 2004). Als gevolg van het zogenaamde 'sorting effect' zal er bij bedrijven met flexibele beloningssystemen zelfselectie plaatsvinden van werknemers die verwachten goed te presteren en beter te verdienen bij prestatiebeloning, en die minder risico-avers staan tegenover flexibele beloning (Lazear, 1986). Daarom kan verwacht worden dat het werknemersbestand binnen een bedrijf zal veranderen als gevolg van de introductie van prestatiebeloning. Conform de theoretische verwachting vinden Gielen e.a. (2006) dat de invoering van prestatiebeloning inderdaad leidt tot een tijdelijke toename van de arbeidsmobiliteit. In de periode waarin prestatiebeloning wordt ingevoerd neemt de personeelsomvang met 3,9 procentpunt extra toe. De uitstroom stijgt met I,2 procentpunt in de eerste periode na de introductie van prestatiebeloning.

Voor oudere werknemers kunnen de effecten van de introductie van flexibele beloning op mobiliteit tweeledig zijn. Enerzijds mag verwacht worden dat oudere werknemers met een relatief lage productiviteit ten opzichte van de beloning, kiezen voor bedrijven met vaste uurlonen, of voor uittrede van de arbeidsmarkt. Anderzijds mag verwacht worden dat oudere werknemers beter in staat zijn dan jongere werknemers om hun eigen productiviteit in te schatten, waardoor ze langer bij dezelfde werkgever zullen blijven als ze eenmaal hun keuze hebben gemaakt voor een flexibel beloningssysteem.

\section{Demotie}

Demotie houdt in dat oudere werknemers in het bedrijf waar ze werken een nieuwe of aangepaste functie krijgen met minder verantwoordelijkheid en een lagere functiewaardering. Op basis hiervan zou verwacht kunnen worden dat oudere werknemers na de demotie een lagere beloning hebben dan ervoor. Demoties zijn, in tegenstelling tot promoties, in de economische literatuur zelden onderzocht.7 Dit komt vooral omdat demoties minder vakk voorkomen dan promoties. Terwijl de economische theorie suggereert dat werknemers worden geplaatst in posities waarin zij het meest

7. Promoties worden uitgebreid besproken in zogenaamde 'incentive' modellen (bijv. 'tournament' modellen). 
productief zijn, valt er geen significante herverdeling van werknemers waar te nemen, vooral niet als sprake is van een neergaande verschuiving (Brüderl (I99I, hoofdstuk 4; Dohmen e.a., 2004). En als demotie al plaatsvindt, dan wordt vaak salariscompensatie geboden aan de werknemer zodat deze ongeveer hetzelfde verdient als voorheen, terwijl de beloning van de desbetreffende werknemer beduidend hoger is dan wat gebruikelijk is voor zijn/ haar status na de demotie.

Brüderl (I99I, hoofdstuk 4) vatte eerdere resultaten in de sociologische literatuur samen en merkt op dat de neoklassieke economische theorie bij het verklaren van demoties enkele fundamentele menselijke behoeften over het hoofd ziet zoals baanzekerheid en baanstatus die beide gerelateerd kunnen worden aan de arbeidsmoraal. Brüderl (I99I) sluit zich hiermee aan bij een eerdere studie van Goldner (1965) die voorstelde dat als demotie strikt noodzakelijk is, een bedrijf gebruik dient te maken van laterale bewegingen op hetzelfde hiërarchisch niveau. Doordat werknemers dan een minder belangrijke functie krijgen op hetzelfde niveau, blijft hun baanstatus behouden. Verder blijkt dat het salaris in bijna alle gevallen gelijk blijft aan de situatie voor demotie. ${ }^{8}$ Eveneens vindt Brüderl (I99I) dat demotie meer acceptabel is als het voortkomt uit de economische situatie waarin het bedrijf zich bevindt.

Eenzelfde resultaat is gevonden in de uitgebreide studie voor de Verenigde Staten van Beweley (I999, zie voornamelijk hoofdstuk I2). In deze studie worden loonreducties geanalyseerd, zowel reëel als nominaal en in verschillende vormen: directe reductie in beloning, bevriezing van beloning zodat de inflatie leidt tot een reële daling in de beloning en reductie in extra beloningen zoals winstdeling. Beweley (1999) vindt dat IO\% van de bedrijven die hij geïnterviewd heeft een reductie in beloning toepaste en 60 bedrijven (26\%) gebruik maakte van bevriezing van beloning voor een periode van een aantal jaren. ${ }^{9}$ Alle bedrijven rapporteren dat beloning wordt beperkt als sprake is van problemen binnen de organisatie. Loonreducties vinden vaker plaats tijdens recessies dan tijdens een hoogconjunctuur. Beweley toont eveneens aan dat reducties in beloning een negatief effect hebben op de motivatie van werknemers. Hij heeft onderscheid gemaakt tussen loonbeperkingen tijdens hoogconjunctuur en laagconjunctuur en vindt dat gedurende een hoogconjunctuur $80 \%$ van de bedrijven een negatief effect op de werkhouding rapporteerde en tevens dat de productiviteit in de helft van de bedrijven negatief werd beïnvloed. Gedurende recessies, hebben werknemers meer begrip voor beleid gericht op demotie.

8. Er bestaat een positieve relatie tussen de hoogte van het loon en motivatie. Als sprake is van incomplete arbeidscontracten en werknemers enige discretie hebben ten aanzien van hun inzet, zullen loondalingen tot kosten leiden voor werkgevers, zelfs als expliciete prestatie-initiatieven bestaan (Fehr en Falk, 1999).

9. De vragen die gesteld zijn aan de bedrijven waren niet gericht op een specifiek tijdsraamwerk. Echter, de vragen hebben betrekking op enkele jaren, aangezien zij gerelateerd zijn aan loonreducties en bevriezing van lonen gedurende de recessie in 1990-1993, de aansluitende hoogconjunctuur of een eerdere recessie. 

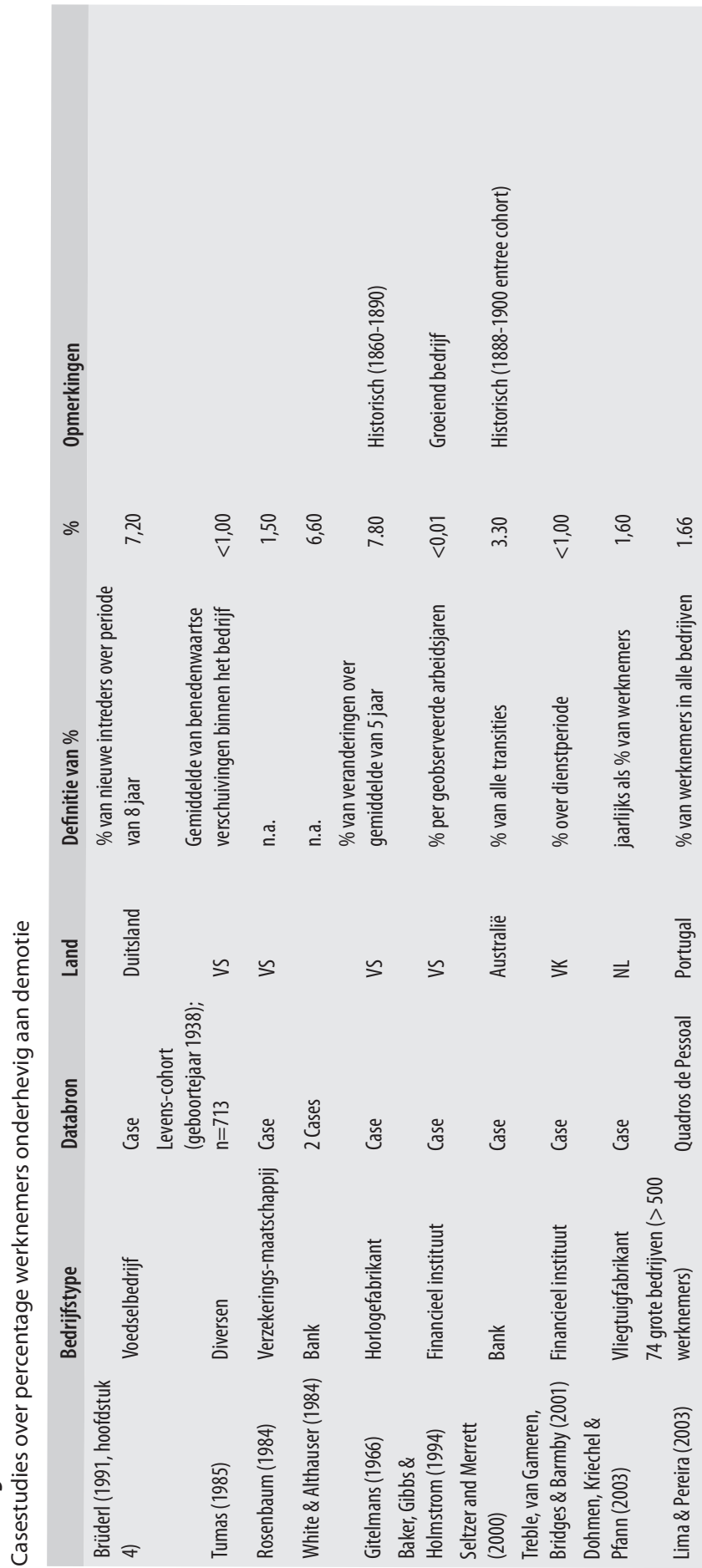
In Tabel 2.3 is een literatuuroverzicht gegeven van recente empirische studies die demotie hebben onderzocht. Uit het overzicht blijkt dat de sociologische literatuur ten aanzien van interne arbeidsmarkten van bedrijven vooral gebruik maakt van bedrijfscasestudies.

Uit het literatuuroverzicht wordt duidelijk dat demotie in zeer beperkte mate wordt toegepast. Het percentage demoties in de tabel varieert tussen $7,8 \%$ tot minder dan ०,०I\%, waarbij de percentages soms over een periode van meerdere jaren gedefinieerd zijn. De percentages demoties zijn overigens moeilijk vergelijkbaar aangezien verschillende definities worden gebruikt en enkele studies gebaseerd zijn op zeer oude data. Zo concentreert Brüderl (I99I, hoofdstuk 4) zich op intreders van een voedselbedrijf in Duitsland, en analyseert hij hoeveel van deze intreders over een periode van 8 jaar achteruit zijn gegaan in positie (7,20\%). Daarentegen vinden Baker e.a. (I994) voor een financieel instituut in de Verenigde Staten dat het percentage demoties lager is dan o,oI\% per geobserveerd arbeidsjaar. Hierbij dient echter wel opgemerkt te worden dat het een groeiend bedrijf betreft. Het toepassen van demotie blijft ook in deze studie beperkt tot bedrijven die in moeilijkheden zijn. Dohmen e.a. (2003) vinden voor de Nederlandse vliegtuigfabrikant Fokker voor de periode 1987-1996 dat jaarlijks slechts I,60\% van de werknemers te maken krijgt met demotie. Lima en Pereira (2003) hebben 74 grote bedrijven geanalyseerd in Portugal en vinden eveneens een bescheiden resultaat. Slechts $\mathrm{I}, 66 \%$ van de werknemers in deze bedrijven krijgt te maken met demotie. 



\subsection{Inleiding}

Dit hoofdstuk beschrijft de data die worden gebruikt bij de analyses in hoofdstuk 4. In de volgende paragraaf wordt ingegaan op de databronnen. Vervolgens wordt in paragraaf 3.3 de verdeling van de loonstructuur naar leeftijd beschreven. In paragraaf 3.4 komt de mobiliteit van werknemers an de orde. Hierbij wordt onderscheid gemaakt tussen uitstroom met vervolgbaan, uitstroom zonder vervolgbaan en instroom. Bovendien worden de gegevens gedifferentieerd naar sector. Tot slot wordt in paragraaf 3.5 gekeken naar de loonsveranderingen van werknemers die wel en niet van werkgever veranderen.

\subsection{Databronnen}

In dit rapport analyseren we de relatie tussen de beloningsstructuur van bedrijven en de mobiliteit van medewerkers. De data zijn afkomstig van het Sociaal Statistisch Bestand (SSB) van het CBS. Het gaat hier om een combinatie van administratieve gegevens (geslacht en leeftijd) van de Gemeentelijke Basisadministratie (GBA) en inkomensgegevens vooral gebaseerd op gegevens van de verzekeringsbank en de belastingdienst. $\mathrm{Zij}$ geven een totaalbeeld van de inkomens van alle in Nederland wonende werknemers in loondienst. Van een groot aantal werknemers zijn ook gegevens bekend uit de Enquête Werkgelegenheid en Lonen (EWL). Groot voordeel van deze bron is dat ook het aantal gewerkte uren per week wordt geregistreerd en dus ook uurlonen kunnen worden berekend. Om die reden beperken we de analyses die betrekking hebben op de loonontwikkeling tot de personen waarvoor EWL-gegevens beschikbaar zijn.

In het onderzoek zullen wij ons richten op de in- en uitstroom van werknemers per organisatie zoals deze door de administratieve data weergegeven worden. De uitstroom wordt bepaald aan de hand van de datum van uitdiensttreding. Sommige mensen zijn 
gelijktijdig bij meerdere werkgevers in dienst. In die gevallen beperken we de analyses tot het contract met het grootste jaarinkomen.

Er is ook nog een viertal restricties op de data toegepast. Om extreem korte contracten met weinig of geen uren buiten de analyses te houden, leggen we op dat een contract minimaal 30 dagen moet zijn. In een jaar moet minimaal I.ooo euro verdiend worden. Voor de regressieanalyses beperken we de waarnemingen tot mensen in de leeftijdgroep 25-59 jaar. Uit analyse van de data blijkt dat bij salarissen van werknemers vanaf 60 jaar relatief vaak exceptionele waardes worden aangetroffen. Het gaat hier waarschijnlijk om eenmalige betalingen die waarschijnlijk ten behoeve van pensioensafkoop dan wel -opbouw gemaakt worden, maar niet als zodanig geïdentificeerd kunnen worden. Hierdoor worden zowel de uurlonen als ook de loonsverschillen verstoord. Een laatste selectie is dat slechts bedrijven en organisaties meegenomen worden die meer dan Io werknemers hebben. Deze restrictie is van belang om bij de regressieanalyses per bedrijf over voldoende waarnemingen te beschikken.

Grotere bedrijven maken vaker deel uit van de EWL dan kleinere bedrijven. Hierdoor zijn grotere bedrijven oververtegenwoordigd in de data. Tabel 3.I laat per jaar zien over hoeveel werknemers en bedrijven er gegevens beschikbaar zijn. Uit de tabel blijkt dat in 2004 een kwart van de werknemers een baan heeft bij een bedrijf met een omvang van ten hoogste 300 personeelsleden. Deze werknemers zijn werkzaam bij relatief veel kleine bedrijven, dat wil zeggen dat de percentielverdeling van de bedrijven niet overeenkomt met die van de werknemers. Een kwart van de werknemers werkt in bedrijven met ten minste 3.250 werknemers. Zij zijn werkzaam bij een beperkt aantal bedrijven.

Tabel 3.1

Aantal werknemers in de geanalyseerde data, verdeling van het aantal personen in een organisatie, en aantal organisaties over tijd

\begin{tabular}{|c|c|c|c|c|c|c|}
\hline & & 2000 & 2001 & 2002 & 2003 & 2004 \\
\hline Totaal aantal werknemers & & 1.793 .954 & 1.913 .360 & 2.146 .873 & 2.253 .736 & 2.435 .261 \\
\hline \multirow[t]{3}{*}{ Werknemers per bedrijf } & $\mathrm{P}_{25}$ & 228 & 239 & 261 & 298 & 300 \\
\hline & $P_{50}$ & 888 & 881 & 891 & 1.053 & 1.030 \\
\hline & $P_{75}$ & 3.999 & 3.678 & 2.913 & 3.293 & 3.250 \\
\hline Aantal bedrijven & & 9.265 & 9.473 & 8.227 & 12.210 & 9.876 \\
\hline
\end{tabular}

Het uurloon wordt gedefinieerd als het fiscale jaarinkomen gedeeld door het aantal in dat jaar gewerkte uren in een bedrijf. In de analyses gebruiken we de logaritme van dit uurloon. De loonsverandering is het verschil in log uurlonen van het huidige jaar ten opzichte van het voorgaande jaar. 


\subsection{Lonen}

Figuur 3.I laat de leeftijdsopbouw van de beloningsstructuur in 2004 zien. Per leeftijd tussen 26 en 59 jaar geeft deze figuur het Io-de, 30-ste, 50-ste, 70-ste en 90-ste percentiel van het uurloon weer. Bij 26-jarigen is de loonsverdeling nog relatief compact. Vooral tussen 26 en 36 jaar neemt de spreiding in de beloning sterk toe. Het 90-ste percentiel stijgt veel sterker dan het Io-de percentiel. Bij 36-jarigen in 2004 was het uurloon van het 90-ste percentiel 26 euro. Dat is $44 \%$ meer dan het 90-ste percentiel van 26 -jarigen (I8 euro). Bij het Io-de percentiel is dit verschil aanzienlijk kleiner. Bij 26-jarigen is het Io-de percentiel Io euro en bij 36-jarigen II euro. Dit is een stijging van $8 \%$. Ook daarna blijft de loonsongelijkheid stijgen, maar neemt het tempo van deze stijging af. Een vergelijking van de beloning van 36-jarigen met 56-jarigen levert veel kleinere verschillen op. De beloning van het 90 -ste percentiel van de 56 -jarigen is 31 euro. Dit is een $19 \%$ meer dan het 90-ste percentiel van de 36-jarigen. Bij het Io-de percentiel is de beloning van 56-jarigen vrijwel gelijk aan de beloning van 36-jarigen. Het verschil bedraagt slechts $3 \%$. Het beeld voor de jaren $1999-2003$ is vrijwel gelijk aan dit beeld voor 2004 .

Figuur 3.1

10-de, 30-ste, 50-ste, 70-ste en 90-ste percentiel van het uurloon naar leeftijd, 2004

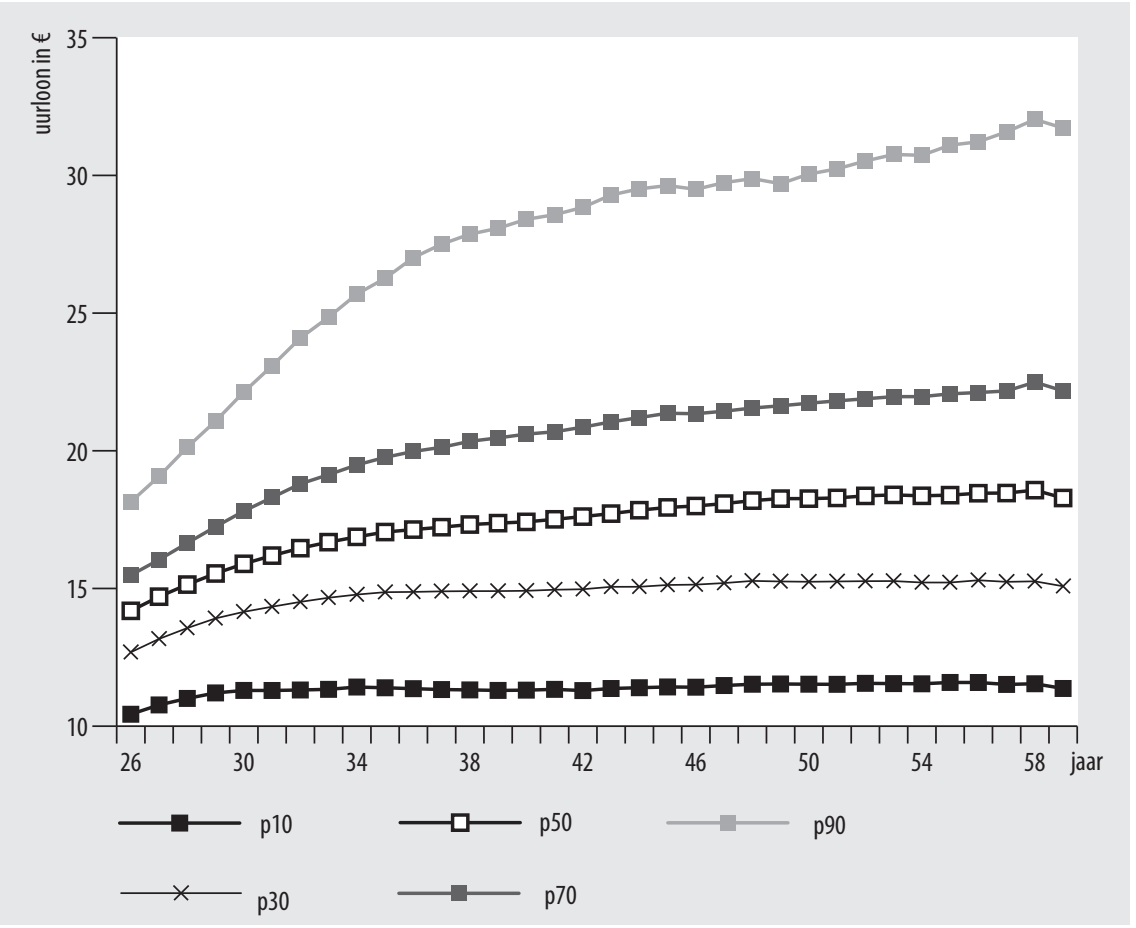

Op basis van de beschikbare data kunnen de beloningen van werknemers over de tijd worden gevolgd. Hierdoor kan ook expliciet de groei van de beloning in kaart worden 
gebracht. Figuur 3.2 laat voor de mediane werknemer deze loongroei voor de jaren 2000-2004 zien. Het jaar 2000 heeft betrekking op het loon in 2000 ten opzichte van I999, de cijfers van 2004 op het loon in 2004 ten opzichte van 2003.

\section{Figuur 3.2}

Toename van het uurloon van de mediane werknemer per jaar naar leeftijd, 1999-2004

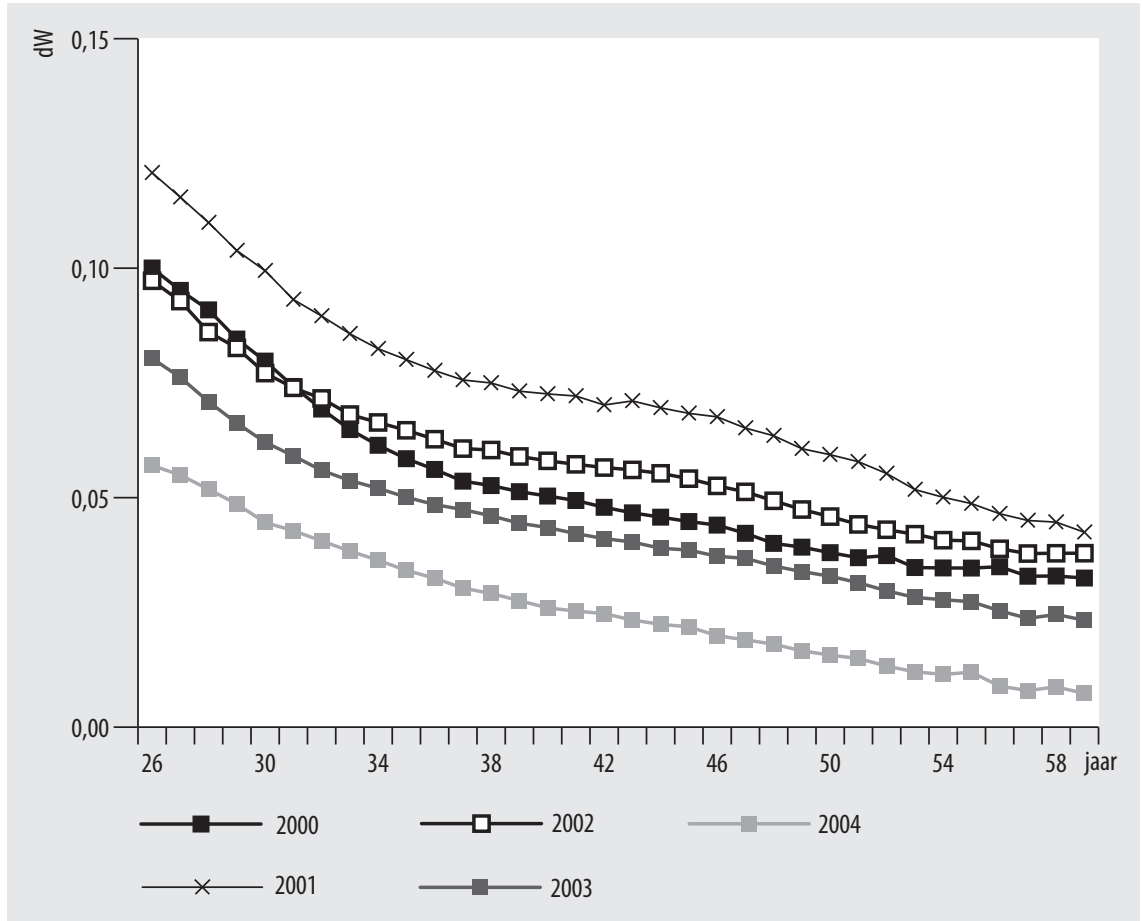

Deze longitudinale cijfers bevestigen dat de loongroei vooral groot is bij de jongere werknemers tussen 25 en 35 jaar. Daarna vlakt de loongroei af. Gemiddeld stijgt echter ook het loon van werknemers tussen de 50 en 60 jaar nog aanzienlijk, gemiddeld ruim $3 \%$ per jaar over deze periode. De leeftijdspatronen op een bepaald moment (i.e. dwarsdoorsnede) verschillen dus van de leeftijdspatronen over de tijd. Terwijl de beloning van ouderen niet veel hoger is dan de beloning van werknemers van middelbare leeftijd, met name aan de onderkant van de loonsverdeling, ondervinden de werknemers van alle leeftijden gemiddeld gesproken een jaarlijkse loongroei. Een interpretatie van de verschillen tussen de leeftijdspatronen in de twee figuren (dwarsdoorsnede en longitudinaal) is echter niet zonder meer te maken, omdat bijvoorbeeld de inflatie wel een rol speelt bij de loongroei van jaar op jaar, maar niet bij de dwarsdoorsnede.

De grafiek laat zien dat de loongroei in 200 I het hoogst was van de periode 20002004, terwijl de laagste loongroei voor 2004 wordt waargenomen. De curves lopen in hoge mate parallel. Dat wil zeggen dat als de gemiddelde loongroei in een jaar hoger 
is, alle leeftijdsgroepen een vergelijkbare verhoging van de loongroei ondervinden. Alleen in 2000-200I bleef de loongroei van ouderen relatief gezien iets achter bij de loongroei van de leeftijdsklasse $25-45$ jaar. Verder is te zien dat in 1999-2000 de loongroei van jongeren tot en met ongeveer 30 jaar relatief groot was.

Figuur 3.3

10-de, 30-ste, 50-ste, 70-ste en 90-ste percentiel van de toename van het uurloon naar leeftijd, 20032004

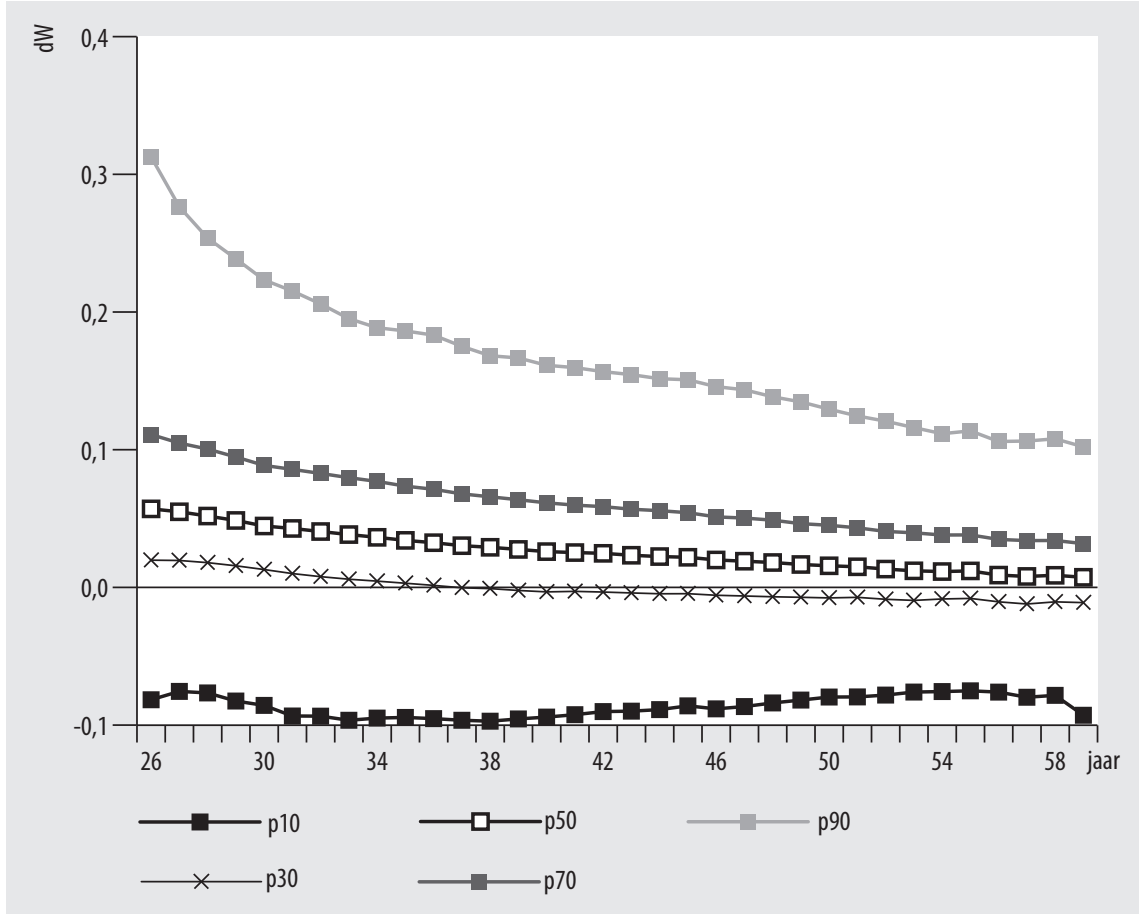

Figuur 3.3 splitst de loongroei tussen 2003 en 2004 uit naar 5 percentielen: I0, 30, 50, 70 en 90 . Het Io-de percentiel van de loongroei in deze periode is voor alle leeftijden negatief. Deze afname van het loon is vrij constant voor de leeftijden en schommelt rond de 9\%. Deze afname kan veel verschillende verklaringen hebben. Zo zijn er altijd werknemers die het jaar ervoor een flinke bonus of incidenteel inkomen hebben ontvangen, eventueel door verrekening met het inkomen in het voorafgaande jaar. Het 90-ste percentiel van de loongroei is veel hoger voor jongere werknemers dan voor ouderen. Bij de 26-jarigen lag dit groeipercentage op $31 \% .{ }^{{ }}$Bij de 36 -jarigen is de groei in het 90 -ste percentiel I $8 \%$ en bij 55 -jarigen is dit nog slechts II\%. Extreme

I. In dit rapport is de loongroei benaderd door het verschil te nemen van de natuurlijke logaritmes tussen twee jaren. Bij hele hoge groeipercentages wijkt de feitelijke gemiddelde loongroei af van deze benadering. In het geval van de 26 -jarigen in figuur 3.3 is de feitelijke loongroei $36 \%$ in plaats van $31 \%$. 
loongroei wordt dus met name aangetroffen bij een klein deel van de jongere werknemers.

\subsection{Mobiliteit}

De figuren 3.4-3.6 geven een beeld van de uit- en instroom in banen. Bij uitstroom maken we een onderscheid tussen uitstroom van de arbeidsmarkt en uitstroom naar een andere baan. Van belang hierbij is dat de eenheid van observatie de baan is en dat deze baan gedefinieerd is als een werkgever-werknemer-relatie. Als een persoon bij een bedrijf komt werken dan start een nieuwe baan. Als hij bij deze werkgever vertrekt dan eindigt de baan. Centraal in dit rapport staat immers de vraag in hoeverre het beloningsbeleid van een bedrijf invloed heeft op de kans dat een werkgever-werknemer-relatie wordt beëindigd. De consequentie hiervan is dat een bedrijf dat steeds voor korte tijd mensen aanneemt, veel werkgever-werknemer-relaties heeft. Bij dergelijke bedrijven worden dus veel nieuwe banen geregistreerd en zal ook de mobiliteit hoog zijn.

\section{Figuur 3.4}

Uitstroom zonder vervolgbaan naar leeftijd, als percentage van het aantal werknemers, 2000-2003

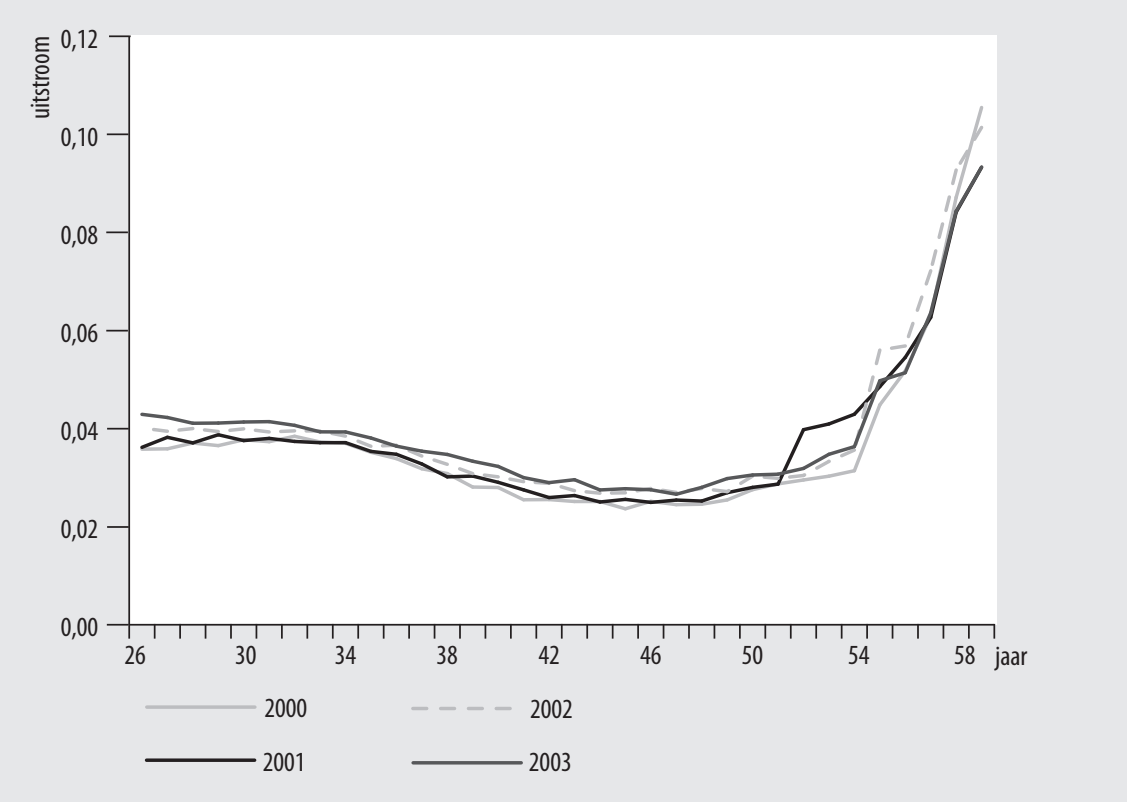

Figuur 3.4 laat zien hoe de uitstroom van werknemers die niet elders gaan werken afhangt van leeftijd. Omdat vervolgbanen niet altijd perfect op elkaar aansluiten en omdat ook de administraties onnauwkeurigheden kunnen bevatten, beschouwen we gevallen waarin mensen die binnen drie maanden een nieuwe baan aanvaarden als 
baan-baan-mobiliteit. Figuur 3.4 laat dus zien welk percentage banen jaarlijks wordt beëindigd, waarbij de werknemer minstens drie maanden na de beëindiging niet elders gaat werken. Bij deze vervolgbanen wordt alle werkgelegenheid in Nederland meegerekend, ook als deze banen niet in de EWL zijn opgenomen. ${ }^{2}$

Voor banen waarin jonge mensen werken blijkt er jaarlijks in zo'n $4 \%$ van de gevallen sprake te zijn van uitstroom waarbij de werknemer niet naar een andere baan gaat. Naarmate werknemers ouder worden neemt dit percentage geleidelijk af tot ongeveer $3 \%$. Vanaf de leeftijd van 55 jaar neemt deze uitstroomkans echter vrij abrupt weer toe. Dit patroon toont duidelijk dat vanaf 55 jaar de uitstroom van werkenden op gang begint te komen, die gebruik maken van mogelijkheden om op de één of andere manier met vervroegd pensioen te kunnen gaan.

Figuur 3.5

Uitstroom met vervolgbaan naar leeftijd, als percentage van het aantal werknemers, 2001-2003

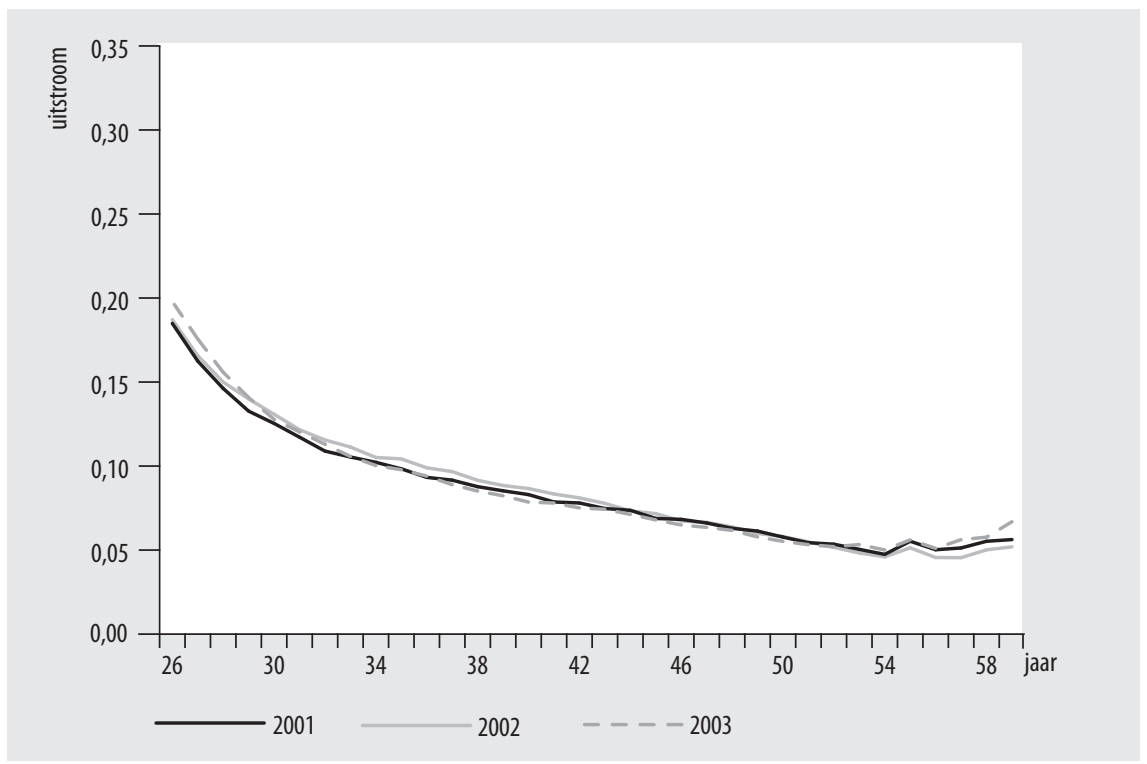

Figuur 3.5 geeft op vergelijkbare wijze de uitstroom van mensen weer die wel binnen drie maanden een nieuwe baan aanvaarden. Deze mobiliteit is vooral bij jongeren hoog. In 200I - 2003 wordt ongeveer een op de vijf banen met jongeren beëindigd en gaat de betreffende persoon in een andere baan werken. Deze baan-baan-mobiliteit neemt vrij snel af met de leeftijd. Op 35-jarige leeftijd gaat het nog maar om één op de tien banen. Daarna daalt dit percentage verder tot ongeveer $5 \%$. Boven de 55 jaar

2. De werknemers die in het buitenland een baan vinden worden dus tot de uitstroom gerekend, en niet bij de baan-baan-mobiliteit. 
neemt de baan-baan-mobiliteit weer licht toe. Mogelijk gaat, bovenop de gewone baan-baan-mobiliteit, een klein deel van de werknemers die gebruik kunnen maken van regelingen om vervroegd uit dienst te gaan, alsnog ergens anders aan de slag. ${ }^{3}$

Figuur 3.6 brengt de instroom in beeld. Ook hier geldt dat de instroom bij nieuwe banen vooral jongeren betreft. Naarmate mensen ouder worden is steeds minder vaak sprake van een nieuwe werkgever-werknemer-relatie. Voorbij 55 jaar neemt de instroom weer enigszins toe, maar het patroon wijkt af van figuur 3.5 omdat ook oudere werknemers die eerder zijn uitgestroomd opnieuw kunnen instromen.

\section{Figuur 3.6}

Instroom naar leeftijd, als percentage van het aantal werknemers, 2000-2003

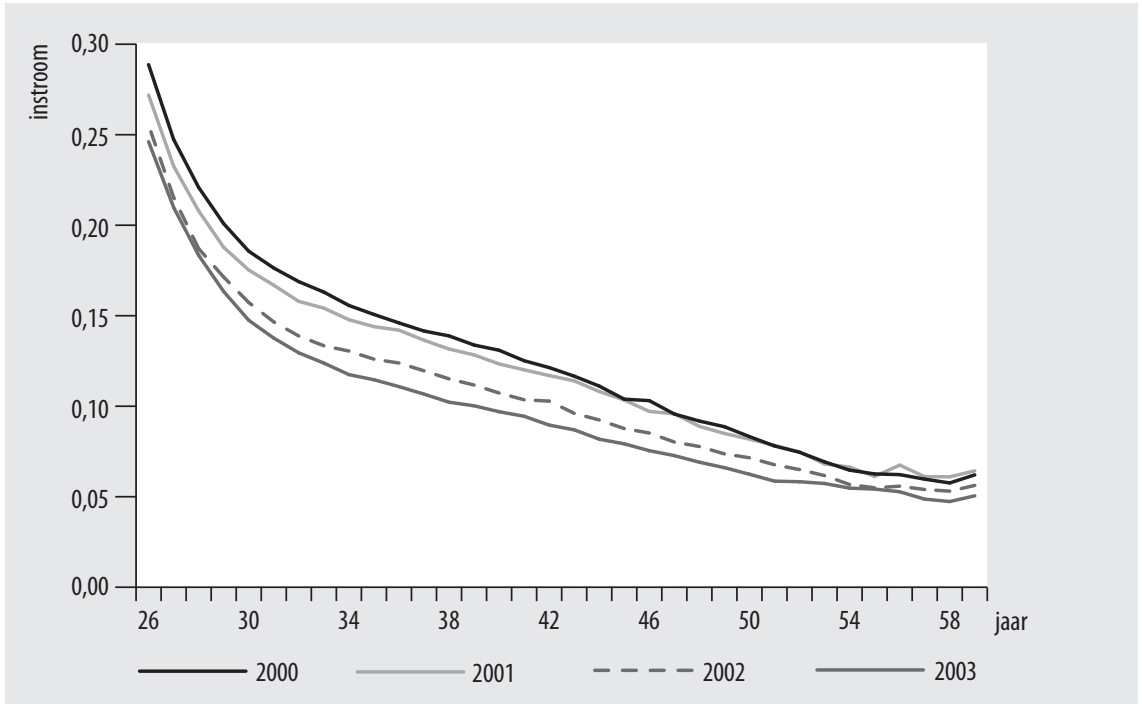

De uitstroom buiten de arbeidsmarkt is vrij gelijkmatig verdeeld over de bedrijfstakken. Tabel 3.2 laat dit zien. Alleen de zakelijke dienstverlening heeft een veel hoger uitstroompercentage dan de andere bedrijfstakken. De oorzaak hiervan is dat de uitzendbureaus in deze bedrijfstak zijn opgenomen. Ook bij de landbouw en in de horeca is door het seizoenskarakter van dit werk, de uitstroom van werkenden die geen nieuwe baan vinden relatief hoog.

3. Voor het jaar 2000 werd er een onwaarschijnlijk hoge uitstroom met vervolgbaan gevonden. De oorzaak hiervan kon niet worden opgehelderd binnen het tijdsbestek van de afronding van dit rapport, maar heeft te maken met de kenmerken van het administratieve gegevensbestand. Het jaar 2000 is daarom niet weergegeven in figuur 3.5. Deze uitstroomgegevens voor het jaar 2000 hebben overigens geen invloed gehad op de analyses of conclusies in de rest van het rapport. 
Tabel 3.2

Uitstroom zonder vervolgbaan naar bedrijfstak, 2000-2003

\begin{tabular}{|c|c|c|c|c|}
\hline \multirow[t]{2}{*}{ Bedrijfstak } & 2000 & 2001 & 2002 & 2003 \\
\hline & $\%$ & $\%$ & $\%$ & $\%$ \\
\hline Landbouw & 4,3 & 4,8 & 4,6 & 3,8 \\
\hline Delfstoffen & 6,1 & 2,9 & 3,1 & 4,4 \\
\hline Industrie: voeding & 2,8 & 2,8 & 3,5 & 3,4 \\
\hline Industrie: textiel en leer & 2,8 & 3,2 & 3,7 & 5,0 \\
\hline Industrie: hout & 2,7 & 2,3 & 2,4 & 2,8 \\
\hline Industrie: papier \& drukkerij & 3,7 & 4,6 & 3,1 & 4,3 \\
\hline Industrie: olie & 3,2 & 3,3 & 1,8 & 1,4 \\
\hline Industrie: chemisch & 2,5 & 2,3 & 2,7 & 2,7 \\
\hline Industrie: rubber & 2,2 & 2,3 & 3,1 & 2,6 \\
\hline Industrie: glas & 2,1 & 2,4 & 2,3 & 2,7 \\
\hline Industrie: metaal & 2,2 & 2,3 & 3,4 & 2,7 \\
\hline Industrie: machines & 2,0 & 2,5 & 2,4 & 2,5 \\
\hline Industrie: elektrisch en optisch & 3,4 & 3,1 & 4,5 & 3,8 \\
\hline Industrie: transport & 2,3 & 2,8 & 2,7 & 3,2 \\
\hline Industrie: meubel & 1,8 & 2,0 & 2,3 & 3,2 \\
\hline Industrie: overig & 2,3 & 2,9 & 3,0 & 3,4 \\
\hline Nuts & 3,7 & 2,4 & 3,6 & 2,4 \\
\hline Bouw & 2,6 & 2,4 & 2,6 & 2,6 \\
\hline Handel & 3,5 & 3,7 & 3,8 & 4,1 \\
\hline Horeca & 4,8 & 4,3 & 6,0 & 5,8 \\
\hline Vervoer, opslag en communicatie & 2,6 & 2,9 & 3,8 & 3,3 \\
\hline Financiële instelling & 2,1 & 2,3 & 3,3 & 2,4 \\
\hline Zkl. Dienstverlening & 7,4 & 7,8 & 8,3 & 8,9 \\
\hline Overheid & 1,9 & 2,2 & 2,5 & 2,3 \\
\hline Onderwijs & 2,5 & 2,3 & 2,3 & 2,4 \\
\hline Gezondheid en welzijn & 2,7 & 2,7 & 2,6 & 2,6 \\
\hline Overig & 3,5 & 3,4 & 3,8 & 3,9 \\
\hline Gemiddelde & 3,4 & 3,4 & 3,7 & 3,7 \\
\hline
\end{tabular}

Tabel 3.3 geeft vergelijkbare cijfers voor de baan-baan-mobiliteit. Hierbij zijn de verschillen tussen bedrijfstakken aanmerkelijk groter. Opnieuw zijn het echter de zakelijke dienstverlening, de horeca en de landbouw die uitstroompercentages hebben die veel hoger liggen dan die in de andere bedrijfstakken. Dezelfde dynamiek is terug te vinden bij de instroomgegevens die in tabel 3.4 zijn opgenomen. 
HOOFDSTUK 3

\section{Tabel 3.3}

Uitstroom met vervolgbaan naar bedrijfstak, 2001-2003

\begin{tabular}{|c|c|c|c|}
\hline Bedrijfstak & $\begin{array}{c}2001 \\
\%\end{array}$ & $\begin{array}{c}2002 \\
\%\end{array}$ & $\begin{array}{c}2003 \\
\%\end{array}$ \\
\hline Landbouw & 12,0 & 8,8 & 8,2 \\
\hline Delfstoffen & 2,9 & 3,0 & 4,4 \\
\hline Industrie: voeding & 5,6 & 5,8 & 5,7 \\
\hline Industrie: textiel en leer & 5,2 & 5,5 & 6,2 \\
\hline Industrie: hout & 4,2 & 4,9 & 7,0 \\
\hline Industrie: papier \& drukkerij & 7,7 & 6,5 & 6,5 \\
\hline Industrie: olie & 2,7 & 1,7 & 1,9 \\
\hline Industrie: chemisch & 6,7 & 6,9 & 4,3 \\
\hline Industrie: rubber & 6,0 & 5,5 & 3,9 \\
\hline Industrie: glas & 4,5 & 3,3 & 3,4 \\
\hline Industrie: metaal & 5,0 & 5,0 & 4,5 \\
\hline Industrie: machines & 5,8 & 5,2 & 4,8 \\
\hline Industrie: elektrisch en optisch & 5,0 & 7,6 & 6,1 \\
\hline Industrie: transport & 5,4 & 5,8 & 4,5 \\
\hline Industrie: meubel & 4,2 & 4,9 & 4,5 \\
\hline Industrie: overig & 2,9 & 2,9 & 2,5 \\
\hline Nuts & 9,6 & 14,7 & 5,1 \\
\hline Bouw & 6,7 & 7,6 & 6,6 \\
\hline Handel & 8,9 & 7,8 & 6,8 \\
\hline Horeca & 11,7 & 11,7 & 10,1 \\
\hline Vervoer, opslag en communicatie & 7,3 & 7,2 & 6,5 \\
\hline Financiële instelling & 5,4 & 8,2 & 6,9 \\
\hline Zkl. Dienstverlening & 23,9 & 22,5 & 23,5 \\
\hline Overheid & 4,5 & 4,2 & 4,8 \\
\hline Onderwijs & 6,8 & 7,3 & 7,8 \\
\hline Gezondheid en welzijn & 6,8 & 6,1 & 6,7 \\
\hline Overig & 8,3 & 8,4 & 8,3 \\
\hline Gemiddelde & 8,9 & 8,6 & 8,6 \\
\hline
\end{tabular}


Tabel 3.4

Instroom naar bedrijfstak, 2000-2003

\begin{tabular}{|c|c|c|c|c|}
\hline Bedrijfstak & $\begin{array}{c}2000 \\
\%\end{array}$ & $\begin{array}{c}2001 \\
\%\end{array}$ & $\begin{array}{c}2002 \\
\%\end{array}$ & $\begin{array}{c}2003 \\
\%\end{array}$ \\
\hline Landbouw & 14,6 & 12,5 & 13,3 & 11,1 \\
\hline Delfstoffen & 5,6 & 7,8 & 6,1 & 4,7 \\
\hline Industrie: voeding & 7,7 & 6,8 & 6,1 & 4,8 \\
\hline Industrie: textiel en leer & 7,8 & 7,9 & 5,0 & 4,1 \\
\hline Industrie: hout & 6,4 & 7,5 & 4,2 & 4,3 \\
\hline Industrie: papier \& drukkerij & 10,7 & 10,3 & 7,1 & 7,2 \\
\hline Industrie: olie & 4,2 & 4,2 & 4,2 & 3,0 \\
\hline Industrie: chemisch & 6,1 & 6,3 & 6,9 & 4,1 \\
\hline Industrie: rubber & 7,3 & 5,9 & 4,8 & 5,1 \\
\hline Industrie: glas & 5,4 & 5,1 & 3,1 & 2,9 \\
\hline Industrie: metaal & 5,8 & 5,3 & 3,8 & 3,3 \\
\hline Industrie: machines & 8,3 & 6,6 & 4,3 & 3,3 \\
\hline Industrie: elektrisch en optisch & 6,9 & 7,1 & 4,3 & 3,8 \\
\hline Industrie: transport & 6,8 & 6,0 & 5,4 & 4,6 \\
\hline Industrie: meubel & 5,2 & 5,1 & 3,5 & 3,0 \\
\hline Industrie: overig & 6,2 & 5,8 & 6,0 & 5,5 \\
\hline Nuts & 5,4 & 3,5 & 9,0 & 3,6 \\
\hline Bouw & 9,8 & 8,8 & 7,8 & 6,0 \\
\hline Handel & 12,9 & 12,3 & 9,7 & 7,7 \\
\hline Horeca & 16,5 & 14,6 & 13,3 & 11,6 \\
\hline Vervoer, opslag en communicatie & 10,1 & 8,7 & 6,5 & 6,6 \\
\hline Financiële instelling & 7,3 & 6,9 & 5,0 & 5,3 \\
\hline Zkl. Dienstverlening & 34,7 & 32,6 & 29,2 & 28,7 \\
\hline Overheid & 6,2 & 7,1 & 6,8 & 5,1 \\
\hline Onderwijs & 9,5 & 8,9 & 8,8 & 7,5 \\
\hline Gezondheid en welzijn & 11,2 & 11,9 & 10,4 & 9,2 \\
\hline Overig & 13,2 & 12,9 & 11,3 & 9,3 \\
\hline Gemiddelde & 13,2 & 12,5 & 10,9 & 10,0 \\
\hline
\end{tabular}




\subsection{Mobiliteit en Ionen}

Door de loongegevens te combineren met de mobiliteitscijfers kan bekeken worden wat de verschillen zijn in salarisontwikkeling tussen mensen die blijven werken bij hetzelfde bedrijf en mensen die van baan veranderen. Figuur 3.7 en 3.8 laten voor de periode 2000-200I de loonontwikkeling naar leeftijd zien voor degenen die bij dezelfde werkgever blijven (Figuur 3.7) en degenen die van baan veranderen (Figuur 3.8). Om de spreiding van de loonontwikkeling duidelijk te tonen zijn in Figuur 3.9 en 3. Io percentiellijnen opgenomen.

\section{Figuur 3.7}

Negen percentielen (10-de, 20-ste, ..., 90-ste) van de loonsverandering van werknemers die niet van werkgever veranderen naar leeftijd, 2000-2001

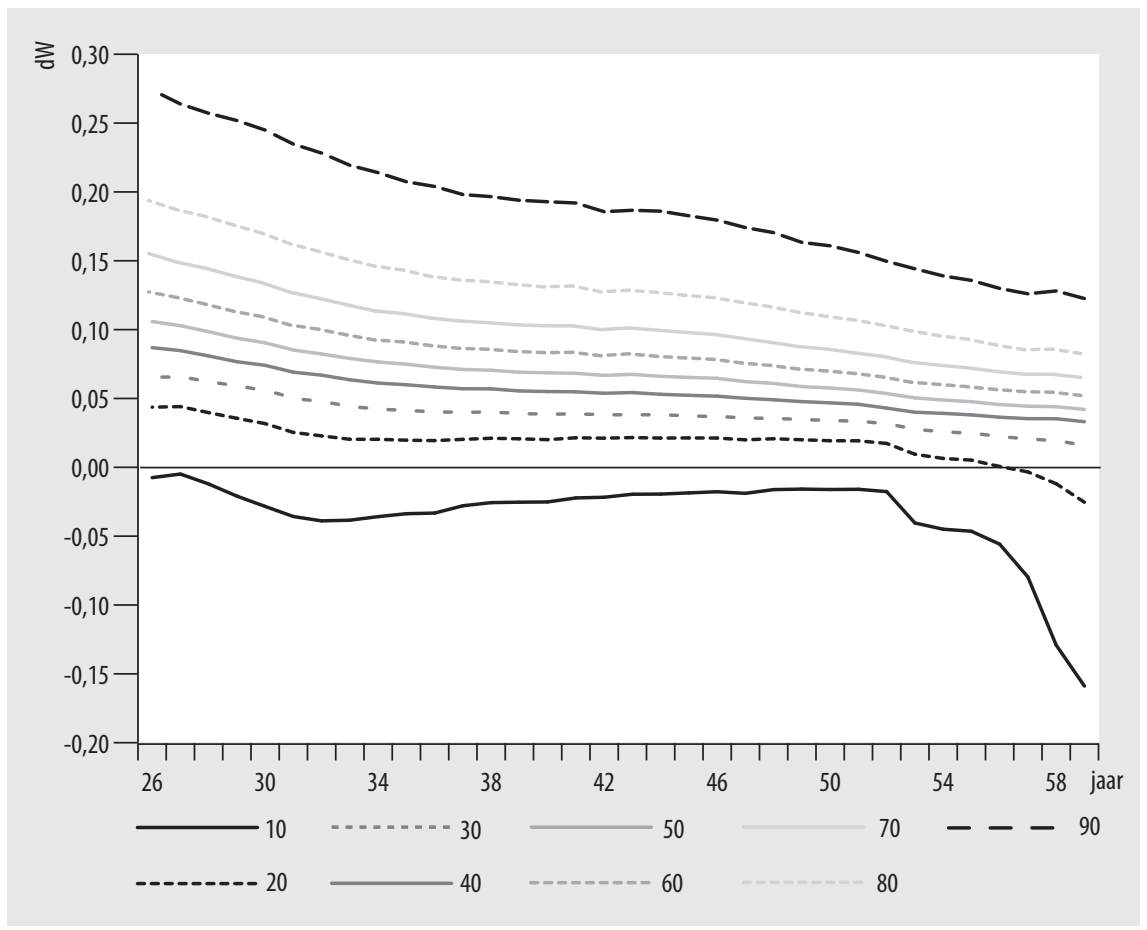

Zowel bij werknemers die bij dezelfde werkgever blijven als bij mensen die van werkgever veranderen is het Io-de percentiel voor de meeste leeftijden negatief. Een uitzondering vormen de jongeren tot en met 36 jaar in figuur 3.8. Ruim IO\% van de werknemer heeft dus te maken met een daling van het inkomen van meestal enkele procenten. In de periode 2000-200I is deze daling bij ouderen iets groter. Ook dit geldt zowel voor de ouderen die bij dezelfde werkgever blijven als voor de ouderen die van werkgever veranderen. Uiteraard moet hierbij opgemerkt worden dat beide 
groepen (degenen die bij hun werkgever blijven en degenen die van baan veranderen) qua achtergrondkenmerken waarschijnlijk erg van elkaar verschillen. Met name bij wat oudere werknemers kan het veranderen van baan in een groot aantal gevallen vrijwillig zijn. Juist degenen die bij een andere werkgever een beter salaris kunnen krijgen zullen dus van baan veranderen, terwijl degenen die moeilijk elders aan een baan kunnen komen, bij hun huidige werkgever blijven. Meer in het algemeen is het overigens van belang op te merken dat hoge en lage percentielen gevoeliger zijn voor toevallige fluctuaties dan de middelste percentielen. De curves zijn daarom iets grilliger voor de hoge en lage percentielen. Als een substantiële groep een afwijkende ontwikkeling doormaakt, eventueel om incidentele redenen, is dit bij het Io-de en 90-ste percentiel duidelijk waarneembaar.

\section{Figuur 3.8}

Negen percentielen (10-de, 20-ste, ..., 90-ste) van de loonsverandering van werknemers die wel van werkgever veranderen naar leeftijd, 2000-2001

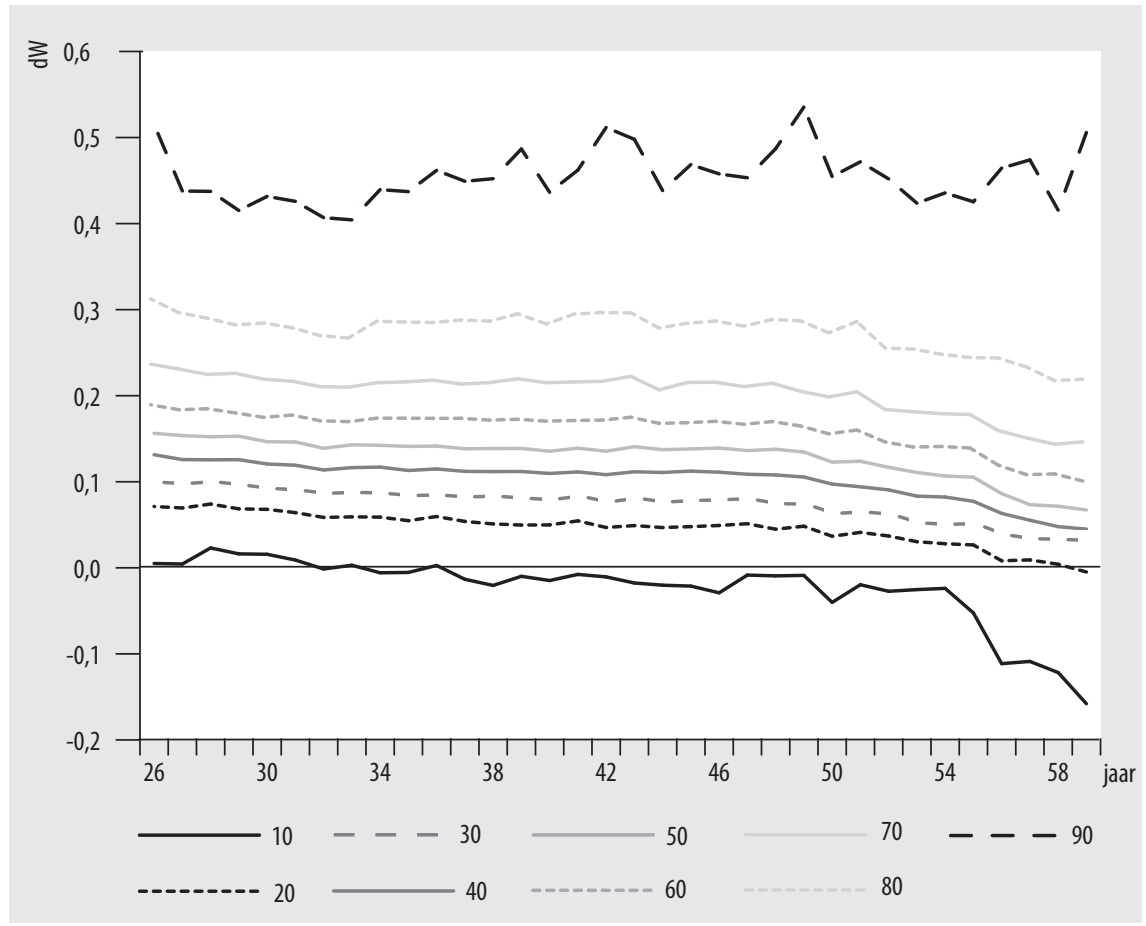

Er is een duidelijk verschil in loonontwikkelingen tussen degenen die bij hun werkgever blijven en degenen die gaan. De laatste groep profiteert van de baanwisselingen door beduidend hogere loonstijgingen dan onder de werknemers die niet van werkgever veranderen. Vooral bij de hoogste percentielen is dit duidelijk te zien. Het 90-ste percentiel voor 26jarigen die bij hun werkgever blijven is $28 \%$, terwijl 26 -jarigen die van werkgever veranderen in het 90-ste percentiel meer dan 50\% in loon stijgen. Voor mensen die niet van baan veran- 
deren neemt de loongroei in alle percentielen geleidelijk af. Voor degenen die wel van baan veranderen is deze groei vrijwel gelijk bij alle leeftijden. Zo weet ook ongeveer IO\% van de $50+$ 'ers die van baan veranderen een loongroei van meer dan 50\% te realiseren.

Hoewel de gemiddelde loongroei per jaar aanzienlijk kan verschillen, zijn de leeftijdspatronen grosso modo aan elkaar gelijk. Figuur 3.9 en 3.IO geven vergelijkbare gegevens voor de periode 2002-2003. De loongroei in deze periode is gemiddeld lager dan in 2000-200I. Bij degenen die niet van baan veranderen is dit bij alle percentielen te zien. Voor degenen die wel van baan veranderen is het 90-ste percentiel echter aanmerkelijk hoger. Waarschijnlijk komt dit doordat mensen minder snel van baan veranderen, waarbij juist degenen die een zeer hoge loongroei kunnen realiseren wel nog mobiel zijn. De opmerkelijke daling bij het Io-de percentiel bij ouderen blijkt specifiek te zijn voor 2000-200I. In de andere periodes wordt dit niet aangetroffen. Uit figuur 3.Io blijkt tevens dat het 90-ste percentiel van de werknemers die van baan veranderen een extreme loongroei doormaakt.

\section{Figuur 3.9}

Negen percentielen (10-de, 20-ste, ..., 90-ste) van de loonsverandering van werknemers die niet van werkgever veranderen naar leeftijd, 2002-2003

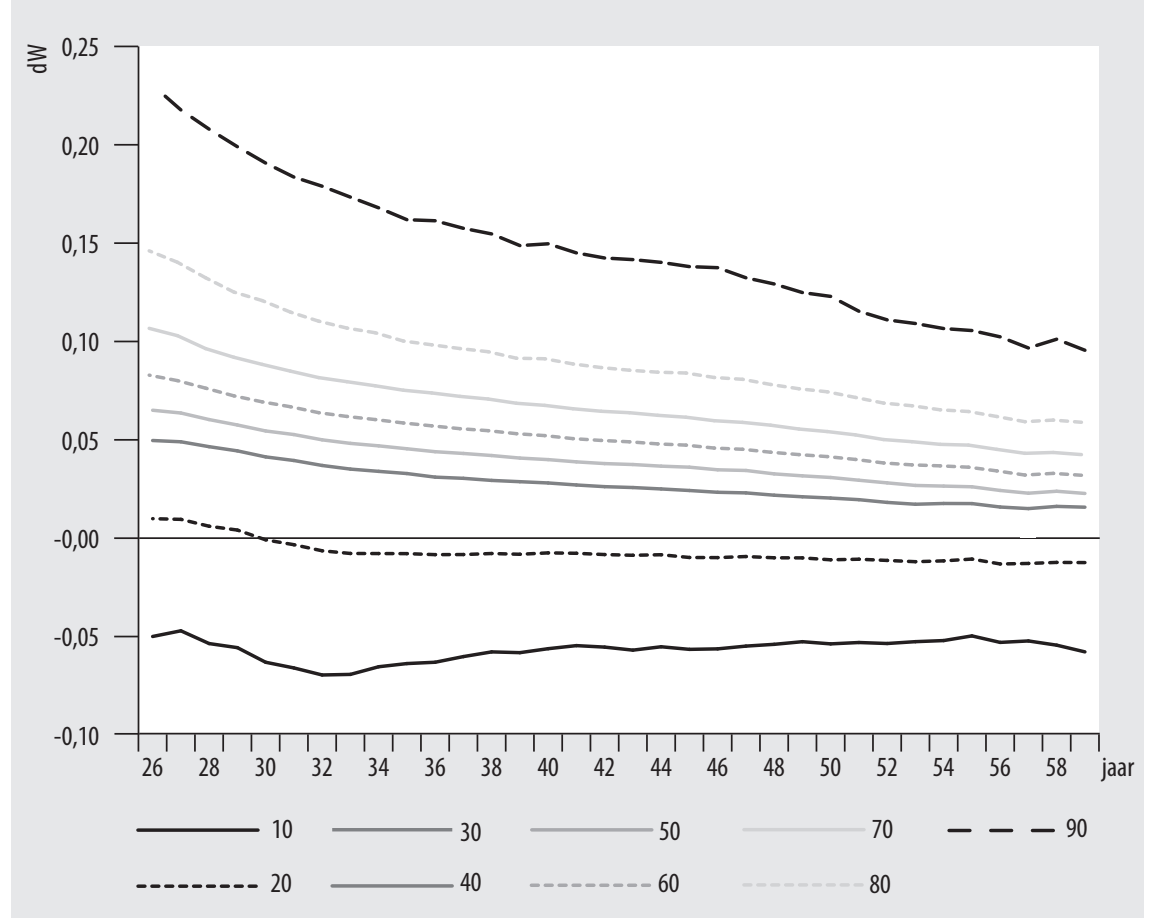




\section{Figuur $\mathbf{3 . 1 0}$}

Negen percentielen (10-de, 20-ste, ..., 90-ste) van de loonsverandering van werknemers die wel van werkgever veranderen naar leeftijd, 2002-2003

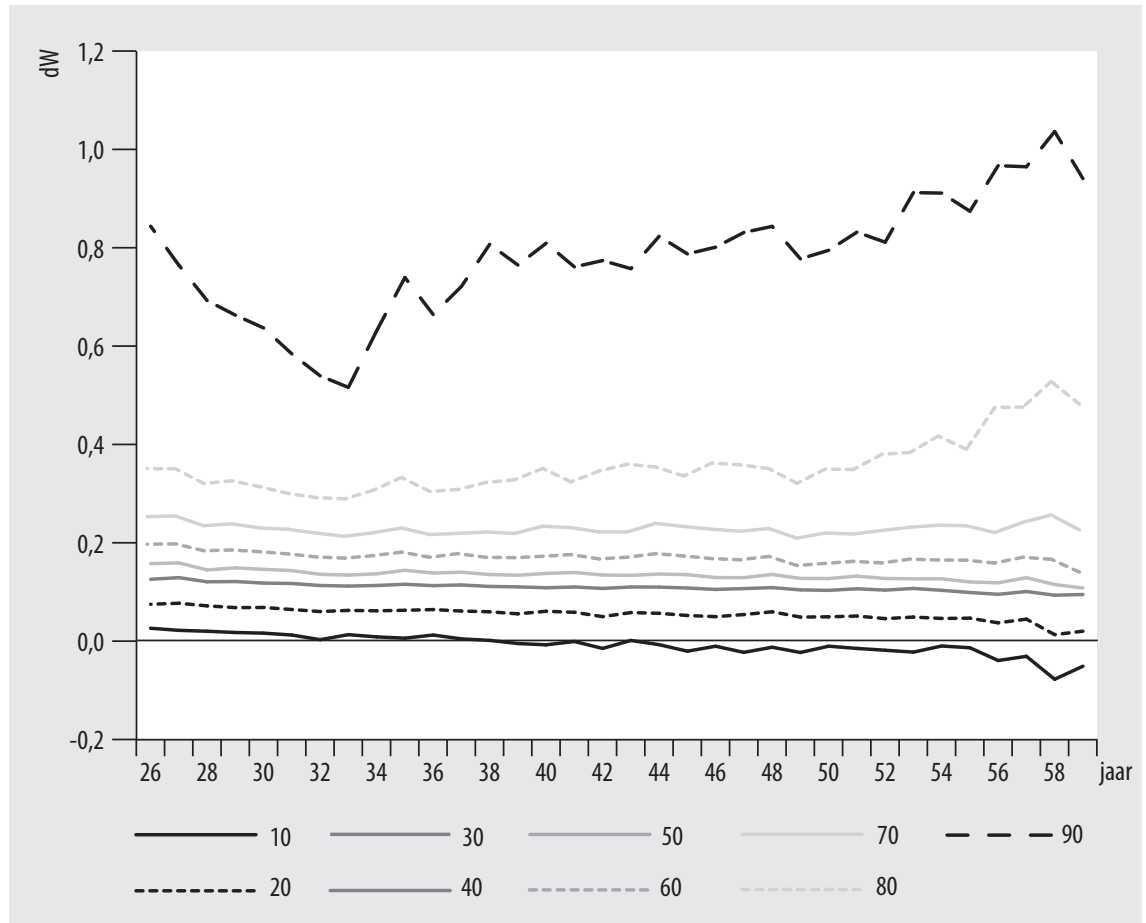





\section{Analyses}

\subsection{Inleiding}

In dit hoofdstuk wordt het verband geanalyseerd tussen de beloningsstructuur van bedrijven en de mobiliteit van werknemers op de arbeidsmarkt, in het bijzonder de uitstroom van ouderen. In de volgende paragraaf wordt ingegaan op de loonvergelijking die per bedrijf is geschat. Hierbij komen de voor dit rapport drie belangrijke kenmerken van de beloningsstructuur van bedrijven aan de orde. In paragraaf 4.3 worden de residuen van de loonvergelijking nader bekeken. In paragraaf 4.4 wordt ingegaan op de verdeling van bedrijven naar de drie kenmerken van de beloningsstructuur. Tot slot wordt in paragraaf 4.5 de relatie tussen de drie beloningskenmerken en de mobiliteit onderzocht.

\subsection{Loonvergelijking}

Om de beloningsstructuur van bedrijven te kunnen typeren wordt per bedrijf een loonvergelijking geschat. De parameters van deze schattingen dienen als indicatoren voor de wijze waarop het bedrijf werknemers beloont. Omdat deze indicatoren goed interpreteerbaar te houden en om ook typeringen van kleine bedrijven mogelijk te maken is een eenvoudige specificatie van de loonsvergelijking nodig. Hiervoor is een aantal mogelijke specificaties getest, waarbij een afweging moest worden gemaakt tussen aan de ene kant de nauwkeurigheid waarmee het verband tussen loongroei en leeftijd werd weerspiegeld, en aan de andere kant de stabiliteit van de parameters en de interpreteerbaarheid van de gegevens. Gekozen is voor een specificatie waarbij de loongroei geschat wordt als lineaire functie van leeftijd.

De individuele loongroei, $\mathrm{d} w_{i}$, is gedefinieerd als het verschil tussen $\log$ (uurloon) en $\log$ (uurloon) van de voorafgaande periode voor het individu (i).

$$
\mathrm{d} w_{i}=a_{f}+b_{f} \text { leeftijd }_{i}+e_{i} \quad \text { met } s d\left(e_{i}\right)=s d_{f}
$$

In deze specificatie weerspiegelt het intercept, $a_{f}$, de gemiddelde groei van de lonen in een jaar van het betreffende bedrijf. Het subscript $f$ verwijst naar parameters die 
kunnen verschillen op bedrijfsniveau. Omdat lonen als logaritme zijn opgenomen kunnen loonsveranderingen als percentages geïnterpreteerd worden. De $b_{f}$ coëfficiënt van leeftijd is te interpreteren als een leeftijdsafhankelijke loonontwikkeling. Om multicollineariteit tussen $a$ en $b$ bij de regressievergelijking van de uitstroom (zie vergelijking (2) in paragraaf 4.5 ) te vermijden wordt leeftijd gemeten als de werkelijke leeftijd minus 40 jaar. ${ }^{I}$ De vergelijking wordt per bedrijf geschat. Het subscript $i$ verwijst naar individuele gegevens, en $e_{i}$ is derhalve de storingsterm van de geschatte vergelijking op individueel niveau. De standaarddeviatie van de storingsterm is dus bedrijfsspecifiek en weerspiegelt een belangrijk kenmerk van de beloningsstructuur.

Het voordeel van een specificatie in termen van loonsveranderingen is dat de schattingen niet beïnvloed worden door individuele verschillen in achtergrondkenmerken tussen werknemers. Bij een specificatie met loonniveaus worden daarentegen impliciet werknemers van verschillende leeftijden met elkaar vergeleken. Als oudere werknemers bijvoorbeeld gemiddeld lager opgeleid zijn dan jongere werknemers en daardoor minder verdienen, dan worden de geschatte coëfficiënten ook door deze verschillen vertekend. Het voordeel van de specificatie met loonsveranderingen is dus dat de beloningen van dezelfde medewerker in twee opeenvolgende jaren met elkaar worden vergeleken. Individuele verschillen die niet veranderen gedurende deze periode vallen daarom uit de vergelijking en kunnen de resultaten niet beïnvloeden. Overigens blijken de resultaten die verkregen worden met alternatieve specificaties van de loonsveranderingen niet sterk af te wijken van de eenvoudige specificatie in vergelijking (I).

De drie geschatte parameters weerspiegelen drie essentiële kenmerken van de beloningsstructuur van een bedrijf. $a_{f}$ geeft aan of de gemiddelde loonstijging van een 40jarige werknemer in een bedrijf hoog of laag is. De leeftijdscoëfficiënt $b_{f}$ geeft aan in hoeverre de loonsstijging in het bedrijf voor ouderen afwijkt van de loonsstijging van jongeren. De standaarddeviatie van de storingsterm $s d_{f}$ geeft aan hoeveel variatie er binnen het bedrijf voorkomt ten opzichte van dit algemene patroon. Dit kan worden gezien als een indicator van de vrijheid die het bedrijf heeft om op individuele basis de lonen van werknemers vast te stellen.

Vergelijking (I) is in eerste instantie per afzonderlijk jaar geschat. Hierdoor kon geanalyseerd worden in hoeverre de drie parameters structurele kenmerken van de bedrijven aan het licht brengen. De correlaties tussen de coëfficiënten in de verschillende jaren bleken inderdaad significant te zijn. Voor de analyses in de paragrafen 4.3, 4.4 en 4.5 kon daarom per bedrijf het gemiddelde van de voor elk van de vier jaren afzonderlijk

I. Door deze aanpassing veranderen de schattingsresultaten $b$ en $\mathrm{R}^{2}$ niet. De schatting van de parameter $a$ verandert uiteraard wel. De standaardfout van $a$ wordt door de aanpassing kleiner. Voor de schattingen die hier zijn uitgevoerd kan worden aangetoond dat de correlatie tussen $a$ en $b$ het kleinste is als er 40 jaar van de leeftijdsvariabele wordt afgetrokken. De parameter $a$ dient te worden geïnterpreteerd als de gemiddelde loonstijging van 40-jarigen per bedrijf. In dit rapport wordt kortweg verwezen naar de 'gemiddelde loonstijging per bedrijf'. 
geschatte coëfficiënten worden genomen. Het gaat dus voor elk bedrijf om gemiddelde coëfficiënten van elk van de drie parameters voor de periode 2000-2004.

\subsection{Analyse van de residuen}

Bij de analyse van de 'fit' van het regressiemodel is het met name van belang dat de eenvoudige structuur niet al te restrictief is en daardoor een vertekend beeld geeft van de loonsontwikkelingen naar leeftijd. In deze paragraaf wordt daarom een foutenanalyse uitgevoerd. De figuren 4.I tot 4.3 laten voor 200 I de verdeling van de voorspelde en de werkelijke loongroei zien voor vergelijking (I). Figuur 4.I geeft de verdeling van voorspelfouten naar leeftijd weer. Er blijkt zoals verwacht kan worden een aanzienlijke individuele voorspelfout te bestaan, maar gemiddeld liggen de fouten niet ver van nul. $\mathrm{Er}$ is in het licht van de variantie die wordt gevonden geen sterk leeftijdseffect in de residuen dat kan wijzen op een serieuze misspecificatie.

\section{Figuur 4.1}

Gemiddelde voorspelfout, en de voorspelfout plus of min één standaard deviatie, vergelijking (1)

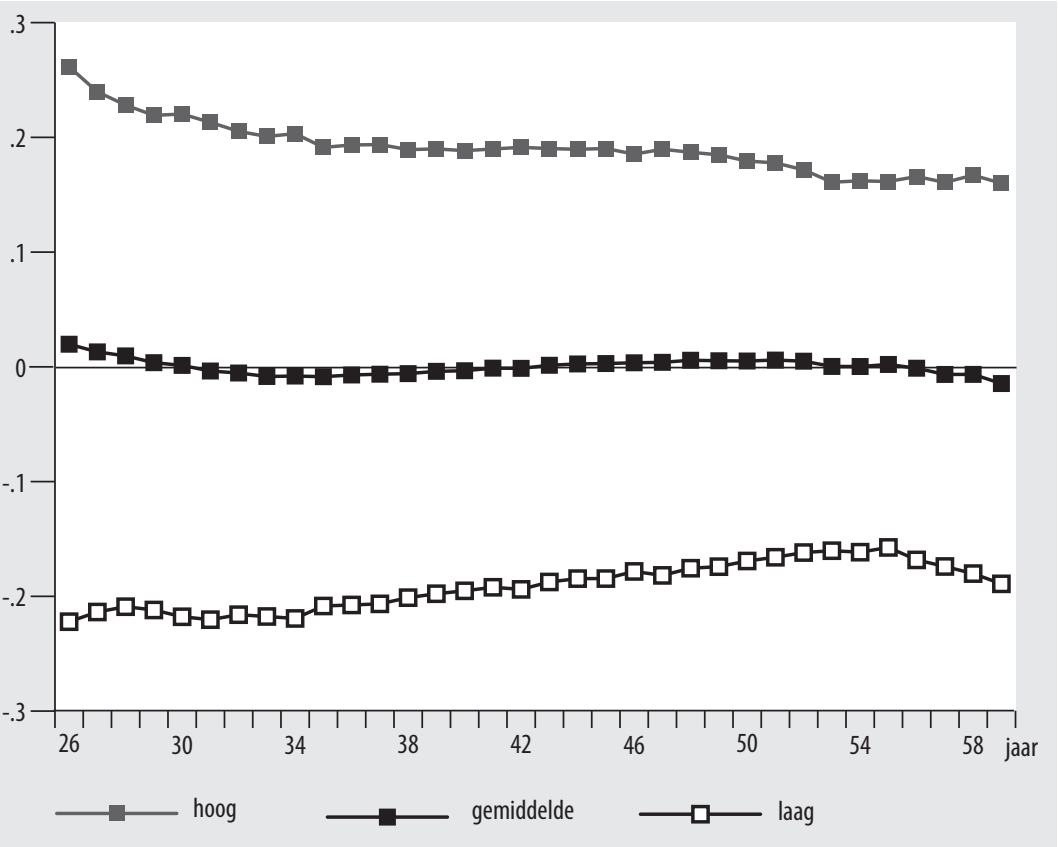

Figuur 4.2 geeft alleen de gemiddelde voorspelfout naar leeftijd weer. Dit is dus een uitvergroting van de middenlijn van figuur 4.I. Nu valt waar te nemen dat het model de loonsverhogingen van jongeren enigszins onderschat en de loonsverhoging van ouderen enigszins overschat. Het gaat hier echter om zeer kleine effecten. 
Figuur 4.2

Gemiddelde voorspelfout uitvergroot, vergelijking (1)

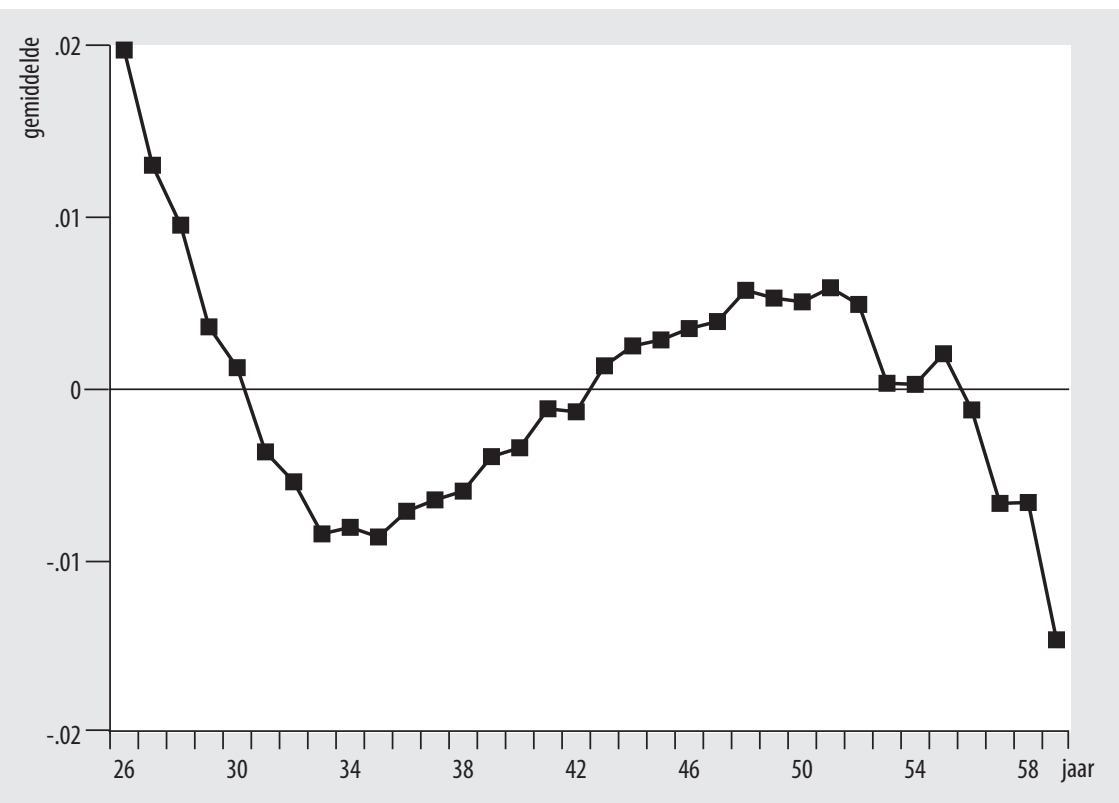

Figuur 4.3

Standaard deviatie van de voorspelfout, vergelijking (1)

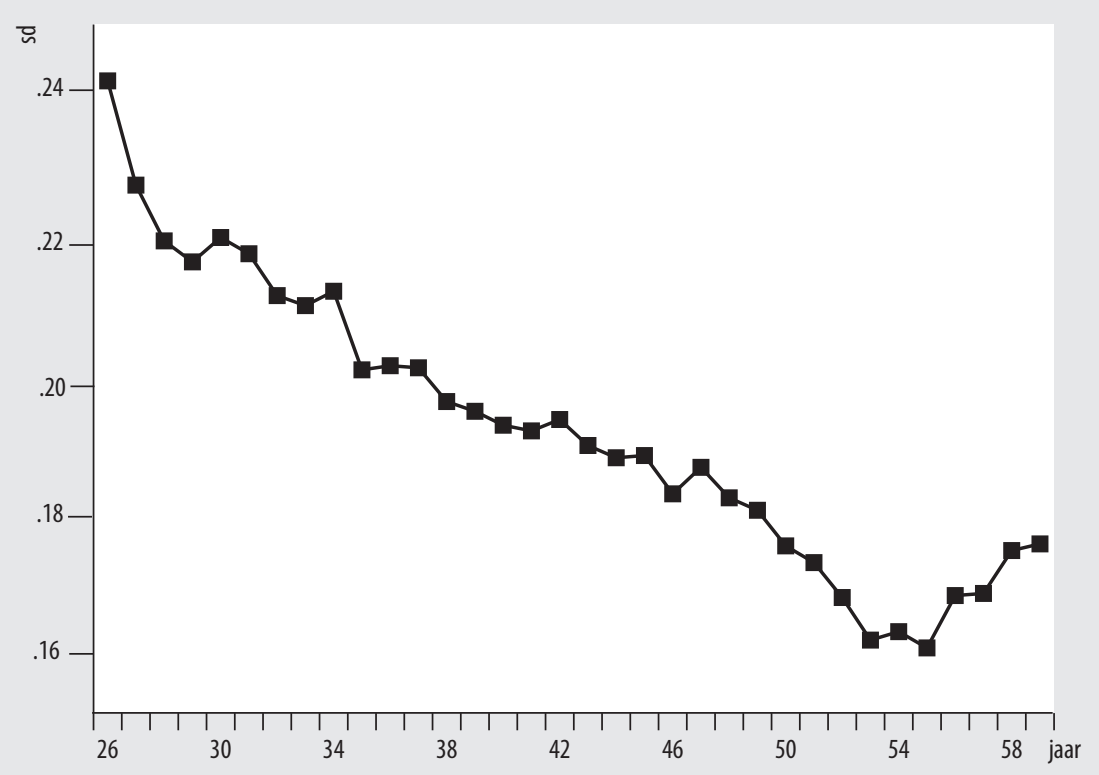


Figuur 4.3 geeft de standaarddeviatie van de voorspelfout weer. De gevolgde methode blijkt de lonen van ouderen beter te voorspellen dan de loonsstijgingen van jongeren.

Om na te gaan of er substantiële verbeteringen geboekt kunnen worden door gebruik te maken van een meer flexibele specificatie is er ook een aantal alternatieve specificaties geschat. Een voorbeeld hiervan is een model waarin een dummyvariabele is toegevoegd om niet-lineaire veranderingen in het leeftijdseffect mee te nemen. De dummy variabele identificeert alle observaties met een leeftijd boven de 45 jaren. Daarnaast is ook geëxperimenteerd met specificaties waarin de standaarddeviatie van de storingsterm een functie van leeftijd is. Deze alternatieve specificaties blijken geen betere 'fit' op te leveren, maar leiden wel tot een veel grotere variatie in de geschatte coëfficiënten, waardoor deze minder goed bruikbaar worden als indicator van het beloningsbeleid van bedrijven.

\subsection{Typeringen van bedrijven}

Ieder bedrijf wordt dus getypeerd door de drie parameters die het gemiddelde weergeven van de schattingscoëfficiënten voor de jaren 2000-2004. Tabel 4.I geeft een beeld van de spreiding van deze kenmerken van de beloningsstructuur. De parameter $a$, die per bedrijf de gemiddelde groei van het loon in de vier onderscheiden periodes weerspiegelt, is positief voor het merendeel van de bedrijven. De mediaan ligt bij een groei van $4,4 \%$ per jaar. Alleen het Io-de percentiel is negatief. De bedrijven met de sterkste loongroei (het 90-ste percentiel) kennen een gemiddeld jaarlijkse loongroei van $9,2 \%$. Het verschil tussen bedrijven met een sterke gemiddelde loongroei en een zeer lage gemiddelde loongroei is dus ongeveer I2 procentpunt.

De coëfficiënt $b$, die het verschil in loongroei tussen oude en jonge medewerkers weerspiegelt, is voor de meeste bedrijven negatief. De mediaan is -0.0009. Dat wil zeggen dat iemand die een jaar ouder is ongeveer O,I procentpunt minder loongroei kent. Bij het Io-de percentiel is deze coëfficiënt -0,004I. Daar daalt de loongroei per leeftijdsjaar met 0,4 procentpunt. Bij ongeveer één op de drie bedrijven is de loongroei van ouderen juist hoger dan van jongeren. In het 90-ste percentiel is deze coëfficiënt 0,003I, zodat dat een leeftijdsjaar 0,3 procentpunt extra loontoename betekent. Het verschil tussen een bedrijf met extreem lage loongroei voor ouderen en bedrijven met extreem hoge loongroei voor ouderen is dus ongeveer 0,7 procentpunt.

De derde coëfficiënt is de standaarddeviatie van de loongroei per bedrijf die niet door leeftijd verklaard kan worden $(s d)$. De mediaan is 0,I9. Het IO-de percentiel van de standaarddeviatie is 0,06 en het 90-ste percentiel 0,33 . Bedrijven met grote variatie in de beloning hebben dus een standaarddeviatie die meer dan vijf maal de standaarddeviatie van bedrijven met een compacte loonsstructuur is. Het verschil tussen deze uitersten is 0,26 . 


\section{Tabel 4.1}

Verdeling van de coëfficiënten naar percentiel, vergelijking (1)

$\begin{array}{lccc}\text { Percentiel } & a & b & s d \\ 10 & -0,0349 & -0,0041 & 0,0623 \\ 20 & 0,0000 & -0,0027 & 0,0990 \\ 30 & 0,0224 & -0,0019 & 0,1300 \\ 40 & 0,0355 & -0,0014 & 0,1586 \\ 50 & -0,0009 & 0,1854 \\ 60 & 0,0443 & -0,0004 & 0,2126 \\ 70 & 0,0522 & 0,0001 & 0,2406 \\ 80 & 0,0606 & 0,0010 & 0,2763 \\ 90 & 0,0714 & 0,0031 & 0,3347\end{array}$

De drie kenmerken staan niet helemaal los van elkaar. Tabel 4.2 laat zien dat er sprake is van enige correlatie tussen deze bedrijfskenmerken. De correlatie tussen $a$ en $b$ is negatief. Dit betekent dat bij bedrijven waar de loongroei relatief hoog is, de ouderen in vergelijking met jongeren een minder sterke loongroei kennen. Bij een sterke loongroei richten bedrijven zich dus meer op de beloning van jongeren dan van ouderen.

Ook tussen $a$ en de standaarddeviatie ( $s d$ ) van de beloning bestaat een negatief verband. Bedrijven met een hoge loongroei differentiëren dus minder tussen hun medewerkers. Het verband tussen $b$ en deze standaarddeviatie is daarentegen positief. Dat betekent dat bedrijven waar de lonen van ouderen relatief veel groeien, ook meer onderscheid tussen medewerkers van dezelfde leeftijd maken bij het vaststellen van de salaristoename.

\section{Tabel 4.2}

Correlaties tussen de coëfficiënten

$\begin{array}{llll} & a & b & s d \\ \text { a } & 1 & & \\ \text { b } & -0,09 & 1 & 1 \\ \text { sd } & -0,24 & 0,12 & \end{array}$

Appendix A bij dit rapport laat zien wat er gebeurt met de beloningsstructuur als de bovenstaande drie kenmerken van bedrijven extreme veranderingen ondergaan. De simulaties geven de verschuivingen in de loonsveranderingen weer als in een bedrijf de $(a)$, de leeftijdsafhankelijke beloning $(b)$ of de beloningsvariatie $(s d)$ veranderen. Het gaat er telkens om dat een bedrijf op een bepaald kenmerk van het Io-de percentiel in de verdeling van het betreffende kenmerk opschuift naar het 90-ste percentiel. 


\subsection{Relatie tussen uitstroom en beloningssystematiek van bedrijven}

Op basis van de typeringen van de beloningssystematiek van bedrijven kan bekeken worden of er een samenhang bestaat tussen de beloningssystematiek en de uitstroom van medewerkers. De samenhang is bepaald door het schatten van een regressievergelijking. In deze vergelijking is de jaarlijkse uitstroom per bedrijf (de te verklaren variabele) een functie van de drie parameters voor het gemiddelde beloningsbeleid van een bedrijf voor de periode 2000-2004 (de verklarende variabelen). ${ }^{2}$ Het gaat hier dus om de geschatte parameters voor de gemiddelde loongroei per bedrijf $\left(a_{f}\right)$, de leeftijdsafhankelijke loongroei per bedrijf $(b)$ en de variatie in de beloning per bedrijf $(s d)$. Verder zijn de schattingen gecorrigeerd voor de leeftijd van de medewerkers $(X)$, en voor de bedrijfstak door het opnemen van sectordummies $\left(D_{s}\right)$. De regressievergelijking is geschat met de kleinste-kwadraten-methode (OLS) en ziet er dus als volgt uit:

$$
\text { (uitstroom per jaar) })_{f}=\mathrm{f}\left(a_{f}, b_{f}, s d_{f}, X_{f}, D_{s}\right)+\mathrm{u}_{f}
$$

Zoals in het inleidende hoofdstuk van dit rapport is beschreven, hoeft het niet zo te zijn dat de uitstroom bij een bedrijf het gevolg is van de beloningsstructuur. Het is ook denkbaar dat een bedrijf kiest voor een bepaalde beloningsstructuur omdat ze geconfronteerd worden met een bepaalde uitstroom. De regressies zijn dus beschrijvend en niet verklarend bedoeld.

Om de omvang van de effecten van de parameters goed te kunnen interpreteren zijn de parameters zodanig geschaald dat het effect overeenkomt met de verandering in uitstroom (of instroom) in procentpunten als de parameters $a, b$ en $s d$ van het Io-de percentiel naar het 90-ste percentiel zouden verschuiven in de verdeling van parameters van bedrijven. Het gaat dus om het verschil in uitstroom bij een verandering in het beloningsbeleid van het ene uiterste naar het ander uiterste. Deze veranderingen in het beloningsbeleid zijn gestileerd weergegeven in Appendix A van dit rapport.

Tabel 4.3 geeft een overzicht van het verband tussen de uitstroom (c.q. instroom) van werknemers tussen 50 en 59 jaar en de drie bovengenoemde parameters voor het beloningsbeleid per bedrijf. De uitstroom in procentpunten dient te worden geplaatst in de context van de uitstroompercentages die in hoofdstuk 3 zijn weergegeven (idem voor instroom). Uit de tabel blijkt duidelijk dat het verband tussen de uitstroom en de beloningsvariatie $(s d)$ binnen bedrijven veel groter is dan het verband tussen uitstroom en de gemiddelde loongroei per bedrijf $(a)$ of de relatieve loongroei van ouderen $(b)$.

2. Doordat puntschattingen uit een eerder model als verklarende variabelen worden gebruikt, worden cöefficiënten van vergelijking (2) enigszins onderschat. 
Tabel 4.3

Relatie tussen de mobiliteit van werknemers 50-59 jaar en de karakteristieken van de beloningsstructuur van bedrijven, mobiliteit in procentpunten, verandering van beloningskenmerk van bedrijf van 10-de naar 90-ste percentiel

\begin{tabular}{|c|c|c|c|c|c|c|}
\hline \multirow{3}{*}{$\begin{array}{l}\text { Mobiliteit 50-59-jarigen en jaar } \\
\text { Uitstroom zonder nieuw werk }\end{array}$} & \multicolumn{2}{|c|}{ Loongroei per bedrijf } & \multicolumn{2}{|c|}{$\begin{array}{l}\text { Relatieve loongroei van } \\
\text { ouderen }\end{array}$} & \multicolumn{2}{|c|}{ Beloningsvariatie in bedrijf } \\
\hline & \multicolumn{2}{|l|}{ a } & \multicolumn{2}{|l|}{$b$} & \multicolumn{2}{|l|}{ sd } \\
\hline & & & & & & \\
\hline 2000 & -0.58 & $(0.11)$ & -0.56 & $(0.11)$ & 6.08 & $(0.14)$ \\
\hline 2001 & -0.70 & $(0.11)$ & -0.79 & $(0.11)$ & 4.91 & $(0.11)$ \\
\hline 2002 & -0.44 & $(0.11)$ & -1.19 & $(0.11)$ & 3.68 & $(0.14)$ \\
\hline 2003 & -0.59 & $(0.11)$ & -0.65 & $(0.11)$ & 3.79 & $(0.14)$ \\
\hline \multicolumn{7}{|l|}{ Uitstroom met nieuw werk } \\
\hline 2000 & -0.05 & $(0.13)$ & -2.26 & $(0.13)$ & 15.15 & $(0.14)$ \\
\hline 2001 & -1.34 & $(0.10)$ & -2.40 & $(0.10)$ & 10.16 & $(0.11)$ \\
\hline 2002 & 2.12 & $(0.11)$ & -1.84 & $(0.11)$ & 8.77 & $(0.11)$ \\
\hline 2003 & 0.88 & $(0.11)$ & -0.82 & $(0.11)$ & 8.26 & $(0.11)$ \\
\hline \multicolumn{7}{|l|}{ Instroom } \\
\hline 2000 & -0.54 & $(0.10)$ & -1.28 & $(0.10)$ & 14.85 & $(0.11)$ \\
\hline 2001 & -1.57 & $(0.10)$ & -1.96 & $(0.10)$ & 13.22 & $(0.11)$ \\
\hline 2002 & -2.41 & $(0.10)$ & -2.50 & $(0.10)$ & 12.54 & $(0.11)$ \\
\hline 2003 & -0.25 & $(0.10)$ & -1.76 & $(0.10)$ & 12.15 & $(0.11)$ \\
\hline
\end{tabular}

Bij de parameter $a$ komt het verschil in uitstroom zonder nieuw werk bij een extreem hoge en lage parameter in een bedrijf niet boven de I procentpunt uit. Uit figuur 3.4 kan worden afgelezen dat deze uitstroom oploopt van ongeveer $3 \%$ voor 50-jarigen tot ca. IO\% voor 59-jarigen. Dat betekent dat de uitstroom van ouderen naar buiten de arbeidsmarkt slechts weinig afneemt bij een marginale toename van de gemiddelde loongroei in bedrijven. Er kunnen twee verklaringen worden gegeven voor de negatieve samenhang tussen de gemiddelde loongroei per bedrijf en de uitstroom naar buiten de arbeidsmarkt:

- Oudere werknemers in bedrijven met hoge gemiddelde loonstijgingen blijven vaker werken bij deze bedrijven dan dat zij de arbeidsmarkt verlaten en genieten van hun vrije tijd. Hiervoor moet verondersteld worden dat het pensioen of de VUT-uitkering niet in dezelfde mate stijgt als het salaris. In dit geval is er dus sprake van een aanbodeffect.

- Bedrijven willen door hoge gemiddelde loonstijgingen te bieden voorkomen dat werknemers de arbeidsmarkt verlaten omdat er veel vraag is naar het type werknemers dat in hun bedrijven werkt. Bedrijven reageren dus met hun loonsstructuur op de vraag naar arbeid en de ontwikkelingen op de arbeidsmarkt. Als deze werknemers ouder worden dan hebben zij weinig prikkels de 
arbeidsmarkt te verlaten en zijn de ontslagkosten voor bedrijven relatief hoog, vooral als de arbeidsmarktpositie voor de oudere werknemers is verzwakt.

De tabel laat verder de relatie zien tussen de gemiddelde loongroei per bedrijf en de uitstroom van oudere werknemers naar ander werk. Deze relatie blijkt overwegend positief te zijn. Hier schommelt de schatting relatief sterk tussen de jaren. Mogelijk heeft de conjunctuur een aanzienlijk effect op dit verband. De gevonden geschatte effecten zijn meestal nog redelijk groot ten opzichte van de absolute uitstroom naar ander werk van ouderen, die voor de meeste jaren en leeftijden ruim $5 \%$ bedraagt, zoals uit figuur 3.5 van het vorige hoofdstuk kan worden afgelezen. Hierbij dient uiteraard bedacht te worden dat het gaat om een extreme verandering in het beloningsbeleid van bedrijven. Een aanbodeffect ligt niet voor de hand om het positieve verband tussen gemiddelde loongroei en uitstroom naar ander werk te verklaren. Dit verband kan het beste worden verklaard doordat bedrijven hun beloning opwaarts aanpassen als veel werknemers naar andere bedrijven vertrekken, vanwege de grote vraag naar dit type werknemer. Omdat de stromen naar buiten de arbeidsmarkt en de stromen naar andere bedrijven deel uitmaken van één simultaan proces, lijkt het er op dat hier vooral vraag- in plaats van aanbodfactoren verantwoordelijk zijn voor de gevonden patronen.

In de tweede kolom wordt het verband op bedrijfsniveau tussen parameter $b$ - die de loongroei weergeeft die gepaard gaat met het ouder worden van werknemers - en de uitstroom weergegeven. De parameter $b$ heeft doorgaans een negatieve waarde, omdat met het vorderen van de leeftijd de loongroei lager wordt. Een hogere $b-$ dat wil zeggen een minder negatieve $b$-impliceert een hogere (i.e. minder negatieve) loonstijging naarmate men ouder is. Uit de tabel blijkt dat een hogere loongroei voor ouderen ten opzichte van jongeren leidt tot een lagere uitstroom naarmate men ouder is. Dat betekent dat de oudere werknemers ten opzichte van de jongere werknemers minder snel naar andere bedrijven vertrekken, en tevens minder snel de arbeidsmarkt verlaten. Ook hier zijn de effecten echter klein. Er kunnen wederom twee verklaringen gegeven worden voor het negatieve verband tussen de relatieve loongroei van ouderen en de uitstroom:

- Het is voor oudere werknemers aantrekkelijk als ze hoge loonstijgingen doormaken ten opzichte van de inkomstenstijgingen bij pensionering of vervroegde uittrede.

- Bedrijven die aan oudere werknemers relatief hoge loonstijgingen geven, zijn ook de bedrijven die ouderen graag willen behouden. Dit kan komen doordat deze bedrijven ouderen in dienst hebben met capaciteiten waarnaar een grote vraag is op de arbeidsmarkt. Het kan bijvoorbeeld gaan om ouderen met kennis en vaardigheden die voor het bedrijf erg belangrijk zijn, en ouderen met een groot leervermogen en ambitieniveau. Deze ouderen selecteren zichzelf in banen en bedrijven met relatief hoge loonstijgingen, zullen pensionering uitstellen en zullen weinig aanleiding hebben om een overstap naar een ander bedrijf te maken. 
In de derde kolom wordt gekeken naar de samenhang op bedrijfsniveau tussen de standaarddeviatie van de beloning $(s d)$ en de uitstroom. Een hoge variantie in de beloning zou kunnen wijzen op een of andere vorm van flexibele beloning zoals prestatiebeloning. De schattingen geven aan dat een hoge variantie in de beloning samengaat met een hoge uitstroom, waarbij er zeer aanzienlijke effecten zijn. Hoewel een meer flexibele beloning de mogelijkheid biedt voor bedrijven om oudere werknemers die minder productief zijn een financiële prikkel te geven om te vertrekken, is de mobiliteit juist veel hoger in bedrijven die meer variatie in de beloning laten zien. Mogelijke verklaringen voor deze samenhang zijn:

- Het gaat om 'dynamische' bedrijven die het belangrijk vinden om een onderscheid tussen (oudere) medewerkers te maken. Voor deze bedrijven zouden de transactiekosten bij de uit- en instroom van personeel minder zwaar kunnen tellen, bijvoorbeeld omdat ze minder last hebben van de schaarste aan personeel met specifieke kennis en vaardigheden. Ze maken meer onderscheid in de beloning dan het gemiddelde bedrijf, en laten ook vaker medewerkers al dan niet vrijwillig het bedrijf verlaten, bijvoorbeeld volgens het 'up or out' principe. Dit betekent overigens dat bedrijven de beloningsstructuur kiezen die het beste past bij de doelstellingen van het bedrijf en de omstandigheden waarin het verkeert.

- De bedrijven trekken medewerkers aan die weliswaar minder risico-avers staan tegenover loonvariaties door een bepaalde vorm van prestatiebeloning, maar een groot deel van deze mensen ontdekt na enige tijd dat men toch een lagere productiviteit (en daardoor een lagere beloning) bereikt dan verwacht. Daardoor vertrekken zij weer. Indien men wel succesvol is kan een hoge productiviteit worden bereikt en blijft men juist langer bij het betreffende bedrijf werken. Dat laatste zou dus in grote mate voor de oudere werknemers kunnen gelden. ${ }^{3}$

In tabel 4.4 wordt hetzelfde overzicht als in tabel 4.3 gegeven maar nu voor alle werknemers tussen 25 en 59 jaar in plaats van alleen de werknemers van 50 tot en met 59 jaar. Uit de vergelijking tussen beide tabellen blijkt dat de relatie tussen de gemiddelde beloning binnen bedrijven ( $a$ ) en de uitstroom (c.q. instroom) over het algemeen iets sterker (positief of negatief) is voor ouderen dan gemiddeld. Het verband tussen de mate van beloningsdifferentiatie binnen bedrijven $(s d)$ en de uitstroom (c.q. instroom) is voor oudere werknemers juist zwakker dan gemiddeld. Voor de relatieve loongroei van ouderen $(b)$ kan geen min of meer algemene uitspraak voor oudere werknemers worden vastgesteld.

3. De relatie tussen beloningsvariatie en uitstroom blijkt voor ouderen inderdaad kleiner te zijn dan voor de lagere leeftijdsgroepen. Dit wordt verderop bij de tabellen 4.5, 4.6 en 4.7 besproken. 
Tabel 4.4

Relatie tussen de mobiliteit van werknemers tussen 26-59 jaar en de karakteristieken van de beloningsstructuur van bedrijven, mobiliteit in procentpunten, verandering van beloningskenmerk van bedrijf van 10-de naar 90-ste percentiel

\begin{tabular}{|c|c|c|c|c|c|c|}
\hline \multirow{3}{*}{$\begin{array}{l}\text { Mobiliteit 26-59 jarigen en jaar } \\
\text { Uitstroom zonder nieuw werk }\end{array}$} & \multirow{2}{*}{\multicolumn{2}{|c|}{ Loongroei per bedrijf }} & \multirow{2}{*}{\multicolumn{2}{|c|}{$\begin{array}{l}\text { Relatieve loongroei } \\
\text { van ouderen } \\
\text { b }\end{array}$}} & \multicolumn{2}{|c|}{$\begin{array}{l}\text { Beloningsvariatie } \\
\text { in bedrijf }\end{array}$} \\
\hline & & & & & \multicolumn{2}{|l|}{ sd } \\
\hline & & & & & & \\
\hline 2000 & -0.66 & $(0.04)$ & -0.82 & $(0.04)$ & 7.52 & $(0.05)$ \\
\hline 2001 & -0.44 & $(0.04)$ & -0.74 & $(0.03)$ & 5.78 & $(0.03)$ \\
\hline 2002 & -0.38 & $(0.04)$ & -0.98 & $(0.04)$ & 5.45 & $(0.05)$ \\
\hline 2003 & -0.40 & $(0.04)$ & -0.61 & $(0.04)$ & 5.42 & $(0.05)$ \\
\hline \multicolumn{7}{|l|}{ Uitstroom met nieuw werk } \\
\hline 2000 & 0.27 & $(0.06)$ & -2.30 & $(0.05)$ & 19.13 & $(0.05)$ \\
\hline 2001 & -1.09 & $(0.05)$ & -2.23 & $(0.05)$ & 13.98 & $(0.05)$ \\
\hline 2002 & 1.30 & $(0.05)$ & -2.36 & $(0.05)$ & 12.78 & $(0.05)$ \\
\hline 2003 & 0.38 & $(0.05)$ & -1.45 & $(0.05)$ & 11.83 & $(0.05)$ \\
\hline \multicolumn{7}{|l|}{ Instroom } \\
\hline 2000 & -0.46 & $(0.05)$ & -0.98 & $(0.05)$ & 17.30 & $(0.05)$ \\
\hline 2001 & -1.23 & $(0.05)$ & -1.54 & $(0.05)$ & 16.30 & $(0.05)$ \\
\hline 2002 & -2.31 & $(0.05)$ & -1.59 & $(0.05)$ & 16.73 & $(0.05)$ \\
\hline 2003 & -0.11 & $(0.04)$ & -2.16 & $(0.05)$ & 16.81 & $(0.05)$ \\
\hline
\end{tabular}

In de tabellen 4.5 tot en met 4.7 worden de schattingen uitgesplitst naar drie leeftijdsgroepen. Over het algemeen blijkt dat de gevonden coëfficiënten niet sterk verschillen tussen deze leeftijdsgroepen. Bedrijven met een beloningsstructuur die samengaat met een hoge uitstroom, hebben dus een hoge uitstroom in alle leeftijdsgroepen. Het lijkt er niet op dat de positie van ouderen sterker door deze structuur wordt beïnvloed dan de positie van jonge medewerkers of medewerkers van middelbare leeftijd.

Alleen de relatie tussen de beloningsvariatie en uitstroom blijkt voor ouderen kleiner te zijn dan voor de leeftijdsklassen van jongere en middelbare leeftijd. Dit kan verklaard worden doordat bij bedrijven mogelijk (zelf)selectie van werknemers plaatsvindt door een relatief hoge beloningsvariatie, waardoor de 'overgebleven' oudere werknemers er hun individuele comparatieve voordelen beter kunnen benutten (i.e. relatief productief zijn). Daarnaast kunnen ook hogere transactiekosten bij ontslag een verklaring zijn voor de relatief lagere correlatie tussen beloningsvariatie en uitstroom van ouderen. 


\section{Tabel 4.5}

Relatie tussen uitstroom zonder nieuw werk en karakteristieken van de beloningsstructuur naar leeftijd, mobiliteit in procentpunten, verandering van beloningskenmerk van bedrijf van 10-de naar 90-ste percentiel

\begin{tabular}{|c|c|c|c|c|c|c|}
\hline \multirow[t]{2}{*}{ Leeftijdsklasse en jaar } & \multicolumn{2}{|c|}{ Loongroei per bedrijf } & \multicolumn{2}{|c|}{$\begin{array}{l}\text { Relatieve loongroei } \\
\text { van ouderen }\end{array}$} & \multicolumn{2}{|c|}{$\begin{array}{c}\text { Beloningsvariatie } \\
\text { in bedrijf }\end{array}$} \\
\hline & a & & b & & sd & \\
\hline \multicolumn{7}{|l|}{ 26-35 jaar } \\
\hline 2000 & -0.46 & $(0.06)$ & -0.73 & $(0.06)$ & 8.83 & $(0.08)$ \\
\hline 2001 & -0.20 & $(0.06)$ & -0.56 & $(0.06)$ & 6.51 & $(0.08)$ \\
\hline 2002 & -0.43 & $(0.06)$ & -0.86 & $(0.06)$ & 6.49 & $(0.08)$ \\
\hline 2003 & -0.32 & $(0.06)$ & -0.57 & $(0.06)$ & 6.32 & $(0.08)$ \\
\hline Gemiddelde over vier jaar & -0.35 & & -0.68 & & 7.04 & \\
\hline \multicolumn{7}{|l|}{ 36-49 jaar } \\
\hline 2000 & -0.68 & $(0.05)$ & -0.98 & $(0.05)$ & 7.09 & $(0.05)$ \\
\hline 2001 & -0.47 & $(0.05)$ & -0.91 & $(0.05)$ & 5.61 & $(0.05)$ \\
\hline 2002 & -0.21 & $(0.05)$ & -0.99 & $(0.05)$ & 5.37 & $(0.05)$ \\
\hline 2003 & -0.34 & $(0.05)$ & -0.68 & $(0.05)$ & 5.53 & $(0.05)$ \\
\hline Gemiddelde over vier jaar & -0.43 & & -0.89 & & 5.90 & \\
\hline \multicolumn{7}{|l|}{$50-59$ jaar } \\
\hline 2000 & -0.58 & $(0.11)$ & -0.56 & $(0.11)$ & 6.08 & (0.14) \\
\hline 2001 & -0.70 & $(0.11)$ & -0.79 & $(0.11)$ & 4.91 & $(0.11)$ \\
\hline 2002 & -0.44 & $(0.11)$ & -1.19 & $(0.11)$ & 3.68 & (0.14) \\
\hline 2003 & -0.59 & $(0.11)$ & -0.65 & $(0.11)$ & 3.79 & (0.14) \\
\hline Gemiddelde over vier jaar & -0.58 & & -0.80 & & 4.61 & \\
\hline
\end{tabular}

Opmerkingen:

* Tussen haakjes is de standaard fout van de geschatte coëfficiënt weergegeven

* Schattingen van effect van beloningskenmerk op mobiliteit volgens vergelijking (2)

Bij een vergroting van de beloningsvariatie doordat een bedrijf op de verdeling naar beloningsvariatie opschuift van het Io-de naar het 90-ste percentiel, blijkt zowel de totale uitstroom (som van uitstroom zonder en met nieuw werk) als de instroom groter te worden. Per saldo stijgt de uitstroom meer dan de instroom, maar het verschil is het kleinst voor de oudere leeftijdsgroep. Zoals eerder opgemerkt hoeft er echter geen sprake te zijn van een causaal verband in schattingsvergelijking (2). Als er wel sprake zou zijn van een causaal verband, en als een grotere beloningsvariatie binnen een bedrijf zou duiden op het toepassen van meer prestatiebeloning, dan zou meer prestatiebeloning leiden tot een grotere netto uitstroom van jong en oud. Voor de oudere werknemers zou dit effect echter het kleinst zijn. 
Tabel 4.6

Relatie tussen uitstroom met nieuw werk en karakteristieken van de beloningsstructuur naar leeftijd, mobiliteit in procentpunten, verandering van beloningskenmerk van bedrijf van 10-de naar 90-ste percentiel

\begin{tabular}{|c|c|c|c|c|c|c|}
\hline \multirow[t]{2}{*}{ Leeftijdsklasse en jaar } & \multicolumn{2}{|c|}{ Loongroei per bedriif } & \multicolumn{2}{|c|}{$\begin{array}{l}\text { Relatieve loongroei van } \\
\text { ouderen }\end{array}$} & \multicolumn{2}{|c|}{$\begin{array}{c}\text { Beloningsvariatie in } \\
\text { bedrijf }\end{array}$} \\
\hline & a & & $b$ & & sd & \\
\hline \multicolumn{7}{|l|}{ 26-35 jaar } \\
\hline 2000 & 0.62 & $(0.11)$ & -2.13 & $(0.10)$ & 19.70 & $(0.11)$ \\
\hline 2001 & -0.64 & $(0.10)$ & -1.78 & $(0.09)$ & 15.40 & (0.11) \\
\hline 2002 & 1.07 & $(0.10)$ & -2.32 & $(0.09)$ & 14.36 & (0.11) \\
\hline 2003 & 0.46 & $(0.09)$ & -1.48 & $(0.09)$ & 13.08 & (0.11) \\
\hline Gemiddelde over vier jaar & 0.38 & & -1.92 & & 15.63 & \\
\hline \multicolumn{7}{|l|}{ 36-49 jaar } \\
\hline 2000 & 0.08 & $(0.08)$ & -2.51 & $(0.08)$ & 19.05 & $(0.08)$ \\
\hline 2001 & -1.35 & $(0.06)$ & -2.38 & $(0.07)$ & 13.19 & $(0.08)$ \\
\hline 2002 & 1.30 & $(0.08)$ & -2.41 & $(0.07)$ & 11.77 & $(0.08)$ \\
\hline 2003 & 0.18 & $(0.08)$ & -1.47 & $(0.07)$ & 11.04 & $(0.08)$ \\
\hline Gemiddelde over vier jaar & 0.05 & & -2.19 & & 13.76 & \\
\hline \multicolumn{7}{|l|}{ 50-59 jaar } \\
\hline 2000 & -0.05 & $(0.13)$ & -2.26 & $(0.13)$ & 15.15 & (0.14) \\
\hline 2001 & -1.34 & $(0.10)$ & -2.40 & $(0.10)$ & 10.16 & (0.11) \\
\hline 2002 & 2.12 & $(0.11)$ & -1.84 & $(0.11)$ & 8.77 & (0.11) \\
\hline 2003 & 0.88 & $(0.11)$ & -0.82 & $(0.11)$ & 8.26 & (0.11) \\
\hline Gemiddelde over vier jaar & 0.40 & & -1.83 & & 10.59 & \\
\hline
\end{tabular}

Opmerkingen:

* Tussen haakjes is de standaard fout van de geschatte coëfficiënt weergegeven

* Schattingen van effect van beloningskenmerk op mobiliteit volgens vergelijking (2)

Tot slot wordt in tabel 4.8 bekeken of bedrijven met een andere beloningsstructuur van elkaar verschillen in de leeftijdsopbouw van hun personeel. In hoofdstuk 3 is al gebleken dat jongere werknemers doorgaans een hogere loongroei doormaken dan oudere werknemers (zie bijv. figuur 3.2). Bedrijven met een hoge gemiddelde loongroei hebben inderdaad meer jonge medewerkers dan medewerkers van middelbare en hogere leeftijd in dienst. Dit kan komen doordat bedrijven jongeren aannemen tegen een laag loonniveau, waarna zij bij voldoende functioneren een flinke loongroei ondergaan. Een deel van de bedrijven is mogelijkerwijs 'jong en dynamisch', groeit flink en trekt veel jong personeel aan. Tevens kunnen in deze bedrijven grote productiviteits- en loonstijgingen worden gerealiseerd. Bedrijven die oudere medewerkers relatief hoge loonstijgingen geven, hebben ook meer ouderen dan jongeren in dienst, maar vooral meer mensen van middelbare leeftijd. Deze bedrijven kunnen gebaat zijn bij de inzet van meer ervaren personeel. 
Tabel 4.7

Relatie tussen instroom en karakteristieken van de beloningsstructuur naar leeftijd, mobiliteit in procentpunten, verandering van beloningskenmerk van bedrijf van 10-de naar 90-ste percentiel

\begin{tabular}{|c|c|c|c|c|c|c|}
\hline \multirow[t]{2}{*}{ Leeftijdsklasse en jaar } & \multicolumn{2}{|c|}{ Loongroei per bedriif } & \multicolumn{2}{|c|}{$\begin{array}{c}\text { Relatieve loongroei van } \\
\text { ouderen }\end{array}$} & \multicolumn{2}{|c|}{$\begin{array}{c}\text { Beloningsvariatie in } \\
\text { bedrijf }\end{array}$} \\
\hline & a & & $b$ & & sd & \\
\hline \multicolumn{7}{|l|}{ 26-35 jaar } \\
\hline 2000 & -0.51 & $(0.10)$ & -0.69 & $(0.09)$ & 17.06 & $(0.11)$ \\
\hline 2001 & -0.94 & $(0.10)$ & -1.30 & $(0.10)$ & 16.70 & $(0.11)$ \\
\hline 2002 & -2.21 & $(0.10)$ & -0.76 & $(0.09)$ & 18.01 & $(0.11)$ \\
\hline 2003 & 0.20 & $(0.09)$ & -2.46 & $(0.09)$ & 18.56 & (0.11) \\
\hline Gemiddelde over vier jaar & -0.86 & & -1.30 & & 17.58 & \\
\hline \multicolumn{7}{|l|}{ 36-49 jaar } \\
\hline 2000 & -0.58 & $(0.08)$ & -1.07 & $(0.07)$ & 17.88 & $(0.08)$ \\
\hline 2001 & -1.48 & $(0.08)$ & -1.48 & $(0.07)$ & 16.46 & $(0.08)$ \\
\hline 2002 & -2.68 & $(0.08)$ & -2.01 & $(0.07)$ & 16.32 & $(0.08)$ \\
\hline 2003 & -0.43 & $(0.06)$ & -1.96 & $(0.07)$ & 16.05 & $(0.08)$ \\
\hline Gemiddelde over vier jaar & -1.29 & & -1.63 & & 16.68 & \\
\hline \multicolumn{7}{|l|}{ 50-59 jaar } \\
\hline 2000 & -0.54 & $(0.10)$ & -1.28 & $(0.10)$ & 14.85 & (0.11) \\
\hline 2001 & -1.57 & $(0.10)$ & -1.96 & $(0.10)$ & 13.22 & (0.11) \\
\hline 2002 & -2.41 & $(0.10)$ & -2.50 & $(0.10)$ & 12.54 & $(0.11)$ \\
\hline 2003 & -0.25 & $(0.10)$ & -1.76 & $(0.10)$ & 12.15 & $(0.11)$ \\
\hline Gemiddelde over vier jaar & -1.19 & & -1.88 & & 13.19 & \\
\hline
\end{tabular}

Opmerkingen:

* Tussen haakjes is de standaard fout van de geschatte coëfficiënt weergegeven

* Schattingen van effect van beloningskenmerk op mobiliteit volgens vergelijking (2)

Bij bedrijven die gekenmerkt worden door een hoge standaarddeviatie van de beloning werken aanzienlijk meer jongeren. Omdat hier sprake kan zijn van 'jonge en dynamische' bedrijven, zullen ook de risico's groter zijn. Het lijken met name de jongeren te zijn die hierop afkomen. Zij zijn mogelijk minder risico-avers en kunnen wellicht een hoge productiviteit bereiken ten opzichte van ouderen, en beter presteren onder prestatiebeloning. Ook kan er onder de jongeren meer sprake zijn van (zelf)selectie, waardoor degenen die bij een bedrijf blijven een hogere productiviteit en een hogere loongroei kunnen realiseren. 
Tabel 4.8

Relatie tussen de leeftijdsopbouw en karakteristieken van de beloningsstructuur naar leeftijd

\begin{tabular}{|c|c|c|c|c|c|c|}
\hline \multirow[t]{2}{*}{ Leeftijdsklasse en jaar } & \multicolumn{2}{|c|}{ Loongroei per bedrijf } & \multicolumn{2}{|c|}{$\begin{array}{l}\text { Relatieve loongroei } \\
\text { van ouderen }\end{array}$} & \multicolumn{2}{|c|}{$\begin{array}{l}\text { Beloningsvariatie } \\
\text { in bedrijf }\end{array}$} \\
\hline & $\mathrm{a}$ & & $b$ & & $s d$ & \\
\hline \multicolumn{7}{|l|}{ 26-35 jaar } \\
\hline 2000 & 1.97 & $(0.08)$ & -0.94 & $(0.07)$ & 5.71 & $(0.08)$ \\
\hline 2001 & 1.93 & $(0.08)$ & -1.19 & $(0.07)$ & 5.98 & $(0.08)$ \\
\hline 2002 & 2.00 & $(0.08)$ & -1.08 & $(0.07)$ & 6.78 & $(0.09)$ \\
\hline 2003 & 2.06 & $(0.07)$ & -0.55 & $(0.07)$ & 7.88 & $(0.09)$ \\
\hline Gemiddelde over vier jaar & 1.99 & & -0.94 & & 6.59 & \\
\hline \multicolumn{7}{|l|}{ 36-49 jaar } \\
\hline 2000 & -0.79 & $(0.08)$ & 0.84 & $(0.08)$ & -3.05 & $(0.09)$ \\
\hline 2001 & -0.71 & $(0.08)$ & 1.11 & $(0.08)$ & -3.23 & $(0.09)$ \\
\hline 2002 & -0.63 & $(0.09)$ & 1.05 & $(0.08)$ & -3.73 & $(0.10)$ \\
\hline 2003 & -0.76 & $(0.08)$ & 0.81 & $(0.08)$ & -4.22 & $(0.10)$ \\
\hline Gemiddelde over vier jaar & -0.72 & & 0.95 & & -3.56 & \\
\hline \multicolumn{7}{|l|}{ 50-59 jaar } \\
\hline 2000 & -1.39 & $(0.06)$ & 0.22 & $(0.06)$ & -4.35 & $(0.07)$ \\
\hline 2001 & -1.37 & $(0.07)$ & 0.33 & $(0.06)$ & -4.56 & $(0.07)$ \\
\hline 2002 & -1.50 & $(0.07)$ & 0.18 & $(0.07)$ & -5.03 & $(0.08)$ \\
\hline 2003 & -1.42 & $(0.07)$ & -0.01 & $(0.07)$ & -5.82 & $(0.08)$ \\
\hline Gemiddelde over vier jaar & -1.42 & & 0.18 & & -4.94 & \\
\hline
\end{tabular}

Opmerkingen:

* Tussen haakjes is de standaard fout van de geschatte coëfficiënt weergegeven 



\section{Conclusies}

In het voorliggende onderzoek wordt nagegaan hoe het feitelijke beloningsbeleid van bedrijven uitwerkt op de uitstroom van werknemers, in het bijzonder de oudere werknemers. Er is onderzocht wat de consequenties zijn van één van de opties om de arbeidsparticipatie van ouderen te stimuleren, namelijk een meer flexibelere beloning die nauwer aansluit bij de productiviteit van ouderen. Factoren die ervoor kunnen zorgen dat de beloning afwijkt van de geleverde prestatie (i.e. het marginaal product) zijn de impliciete arbeidscontracten tussen werkgevers en werknemers, en de depreciatie van het menselijke kapitaal, die met name een rol speelt bij het ouder worden van werknemers.

Impliciete contracten worden afgesloten om stabiele arbeidsrelaties voor de lange termijn te bewerkstelligen. Kenmerkend voor deze langetermijncontracten is dat zowel de werkgever als de werknemer ermee hebben ingestemd om een deel van de beloning uit te stellen naar het einde van het contract (oplopende loonprofielen), zodat een langetermijnarbeidsrelatie tot stand komt. Dit betekent dat werknemers op jonge leeftijd minder en op oudere leeftijd meer verdienen dan de waarde van hun marginale productiviteit. Daardoor kan de mobiliteit tussen bedrijven en de daaruit voortkomende transactiekosten beperkt gehouden worden, kennen de bedrijven beter de productiviteit van hun werknemers, en kunnen ze de investeringen in de scholing van hun personeel terugverdienen. Bovendien zouden werknemers meer gemotiveerd kunnen zijn om zich in te spannen voor het bedrijf waar ze werken door de oplopende loonprofielen die ze in het vooruitzicht zijn gesteld. Daardoor stijgt de productie bij bedrijven of hoeven ze minder kosten te maken voor de monitoring van de productiviteit van hun werknemers.

Lonen die harder stijgen dan de productiviteit kunnen in een productiviteit-loon-gat resulteren aan het einde van de loopbaan van werknemers. Empirische studies over de verhouding tussen loon en productiviteit over de levenscyclus zijn echter schaars en niet altijd eenduidig, maar lijken het bestaan van een productiviteitsloon-gat bij oudere werknemers te bevestigen. Omdat deze studies alleen toegepast kunnen worden op specifieke beroepen of sectoren waarvoor de productiviteit geobserveerd kan worden, hebben de meeste studies zich gericht op de analyse van het verloop van loonprofielen over de levenscyclus. Uit deze studies blijkt onder meer dat oplopende loonprofielen 
als substituut dienen voor monitoring, vooral als de werkgever de productiviteit van de werknemers moeilijk kan meten.

Behalve de impliciete contract theorie geeft ook de theorie over de depreciatie van menselijk kapitaal aanwijzingen voor het bestaan van verschillen tussen productiviteit en loon bij met name oudere werknemers. Technische depreciatie kan ontstaan als gevolg van slijtage door het natuurlijk verouderingsproces of atrofie door onvoldoende gebruik van vaardigheden. Daarmee is technische depreciatie vaak een geleidelijk proces waarop werkgever en werknemer kunnen anticiperen. Daarentegen is economische depreciatie het gevolg van baanspecifieke depreciatie door technologische en organisatieverandering, die vaak schoksgewijs optreedt. Derhalve zal voornamelijk economische depreciatie resulteren in loon-productiviteit divergenties waarop werknemer en werkgever slechts in beperkte mate op hebben kunnen anticiperen.

Uit de empirische literatuur blijkt dat schoksgewijze technologische verandering over het algemeen leidt tot een verslechtering van de arbeidsmarktpositie van ouderen. De reden hiervoor is dat oudere werknemers over vaardigheden beschikken die relevant zijn voor de oude technologie, terwijl jongere werknemers tijdens hun opleiding vaak leren werken met de nieuwste technologieën. Onder bepaalde omstandigheden kunnen ongeanticipeerde veranderingen echter leiden tot verbetering van hun arbeidsmarktpositie, vooral als nieuwe technologieën complementair zijn met de oude. Hoe technologische schokken de arbeidsmarktpositie van oudere werknemers beïnvloeden blijkt samen te hangen met het personeelsbeleid van werkgevers, en het opleidingsniveau, de werkervaring en het soort menselijk kapitaal dat werknemers bezitten.

In het geval dat technologische schokken leiden tot een verlaagde productiviteit van ouderen, kunnen werkgevers initiatieven ontwikkelen om deze groep werknemers vervroegd te laten uittreden, extra te investeren in de oudere werknemers, demotie toe te passen of de beloning te verlagen. De laatste drie maatregelen zijn erop gericht om de beloning meer in overeenstemming te brengen met de productiviteit van de werknemer. Uit het schaarse onderzoek over demotie blijkt dat dit nog niet veel voorkomt. Als demotie al plaatsvindt, dan wordt vaak salariscompensatie geboden aan de werknemer zodat deze ongeveer hetzelfde verdient als voorheen, terwijl de beloning van de desbetreffende werknemer beduidend hoger is dan wat gebruikelijk is voor zijn/ haar status na de demotie.

In verband met de laatst genoemde maatregel, een lagere beloning voor ouderen, is het relevant om te constateren dat in Nederland het gebruik van flexibele beloningssystemen lijkt te zijn toegenomen gedurende de laatste jaren. Hoewel expliciete productiviteitscijfers op individueel niveau ontbreken, wordt aangenomen dat bedrijven die sterker variëren in de beloning tussen medewerkers, zich wat betreft hun beloningsbeleid meer richten naar de productiviteitsverschillen tussen hun medewerkers. Terwijl prestatiebeloning relatief vaak voorkomt in de bouwsector en de landbouwsector, wordt in het onderwijs en de zorgsector maar in zeer beperkte mate prestatiebeloning 
toegepast. Daarbij speelt dus mee dat productiviteit van individuele werknemers niet in elk beroep of sector kan worden gemeten.

De empirische analyse in dit rapport richt zich op de vraag hoe de beloningssystematiek van bedrijven de mobiliteit en arbeidsparticipatie van oudere werknemers beïnvloedt. Wat betreft de loongroei tussen 2000 en 2004 is gevonden dat deze vooral groot is bij de jongere werknemers tussen 25 en 35 jaar. Daarna vlakt de loongroei af. Gemiddeld stijgt echter ook het loon van werknemers tussen de 50 en 60 jaar nog aanzienlijk. Voor banen waarin jonge mensen werken blijkt er jaarlijks in zo'n $4 \%$ van de gevallen sprake te zijn van uitstroom waarbij de werknemer niet naar een andere baan gaat. Naarmate werknemers ouder worden neemt dit percentage geleidelijk af tot ongeveer 3\%. Vanaf de leeftijd van 55 jaar neemt deze uitstroomkans echter vrij abrupt weer toe, waarschijnlijk doordat men gebruik maakt van de mogelijkheden voor vervroegd pensioen.

De uitstroom door baan-baan-mobiliteit is vooral bij jongeren hoog. In 200I-2003 wordt ongeveer één op de vijf banen met jongeren beëindigd en gaat de betreffende persoon in een andere baan werken. Deze baan-baan-mobiliteit neemt daarna vrij snel af, van IO\% voor 35 -jarigen tot ongeveer $5 \%$ op nog latere leeftijd. Boven de 55 jaar neemt de baan-baan-mobiliteit weer licht toe. De uitstroom buiten de arbeidsmarkt is vrij gelijkmatig verdeeld over de bedrijfstakken. Voor de baan-baan-mobiliteit zijn de verschillen tussen bedrijfstakken aanmerkelijk groter. Zakelijke dienstverlening, de horeca en de landbouw hebben de hoogste uitstroompercentages, zowel buiten de arbeidsmarkt als wat betreft de baan-baan-mobiliteit.

Ruim IO\% van de werknemers heeft tussen 2000 en 2004 te maken met een daling van het inkomen van meestal enkele procenten. Hierbij is geen duidelijk verschil tussen degenen die bij hun werkgever blijven en degenen die de arbeidsmarkt verlaten. Dit is wel het geval bij de hoge salaristoenames: deze zijn veel groter bij degenen die van baan veranderen. Voor mensen die niet van baan veranderen neemt de loongroei in alle percentielen geleidelijk af. Voor degenen die wel van baan veranderen is deze groei vrijwel gelijk bij alle leeftijden. Zo weet ook ongeveer IO\% van de 50+'ers die van baan veranderen een loongroei van meer dan 50\% te realiseren. Hoewel de gemiddelde loongroei per jaar aanzienlijk kan verschillen, zijn de leeftijdspatronen grosso modo aan elkaar gelijk. De loongroei is in 2002-2003 gemiddeld lager dan in 2000-200I.

De centrale vraag in dit rapport is of de voortijdige uitstroom van ouderen van de arbeidsmarkt wordt gereduceerd en hun arbeidsparticipatie gestimuleerd als bedrijven hun beloningsbeleid aanpassen in de richting van meer flexibele beloningssystemen. Om de beloningsstructuur van bedrijven te kunnen typeren wordt per bedrijf een loonvergelijking geschat. De parameters van deze schattingen dienen als indicatoren voor de wijze waarop het bedrijf werknemers beloont. Het betreft drie parameters die de voor onze analyse essentiële kenmerken van de beloningsstructuur van een bedrijf weerspiegelen. Ten eerste de gemiddelde loonstijging van alle werknemers in 
een bedrijf. Ten tweede de mate waarin de loonsstijging in het bedrijf afwijkt tussen oudere en jongere werknemers, met andere woorden de leeftijdsafhankelijke beloning. Ten derde de mate waarin er variatie binnen het bedrijf voorkomt ten opzichte van het algemene patroon van loonstijgingen en leeftijdsafhankelijke beloning. De laatste parameter kan worden gezien als een indicator van de vrijheid die het bedrijf heeft om op individuele basis de lonen van werknemers vast te stellen.

De basisgedachte die in dit rapport geanalyseerd wordt is of de uitstroom van ouderen van de arbeidsmarkt kan worden beperkt, en hun arbeidsparticipatie kan worden vergroot, als bedrijven een meer flexibel beloningsbeleid (i.e. prestatiebeloning) voeren. Uitsluitend bezien vanuit de vraagzijde van de arbeidsmarkt, en onder de veronderstelling dat de productiviteitsontwikkeling van ouderen achterblijft bij hun loonontwikkeling, zal volgens deze redenering de uitstroom van ouder personeel lager zijn naarmate bedrijven de beloning van ouderen sterker neerwaarts aanpassen en naarmate de beloningsstructuur een grotere variatie laat zien. Bezien vanuit de aanbodzijde van de arbeidsmarkt, en onder de veronderstelling van risico-aversie van werknemers tegenover beloningsvariatie, zal een meer flexibel beloningsbeleid daarentegen tot een hogere uitstroom leiden. De uitstroom van ouderen vindt deels plaats naar buiten de arbeidsmarkt omdat de alternatieve kosten van vrije tijd dalen en deels naar bedrijven die belonen op basis van anciënniteit.

Uit de empirische analyse blijkt dat een hoge variantie in de beloning binnen bedrijven - die zou kunnen wijzen op een of andere vorm van prestatiebeloning - er niet toe leidt dat bedrijven oudere werknemers gemakkelijker kunnen behouden. De uitstroom en mobiliteit is voor alle leeftijdsgroepen juist veel hoger in deze bedrijven. Voorts is gevonden dat bedrijven die ouderen een relatief hoge loongroei geven, een lage uitstroom kennen. Bij deze bedrijven is zowel de uitstroom naar buiten de arbeidsmarkt laag, als de uitstroom naar een ander bedrijf. Een aanbodeffect ligt hier niet voor de hand, zodat dit het beste verklaard kan worden doordat bedrijven hun beloning opwaarts aanpassen als veel werknemers naar andere bedrijven vertrekken. In de empirische analyse is tevens gevonden dat een hogere loongroei (voor alle werknemers) samengaat met een lagere uitstroom naar buiten de arbeidsmarkt, en in de meeste jaren ook met een hogere uitstroom naar ander werk.

Voor oudere werknemers lijkt, evenals voor alle andere werknemers, te gelden dat bedrijven goed belonen omdat ze graag hun (oudere) werknemers willen behouden en de kans op uitstroom van hun personeel willen verminderen. Dit lijkt er op te wijzen dat niet de loonsstructuur de uitstroom bepaalt, maar dat omgekeerd bedrijven met hun beloningsbeleid reageren op ontwikkelingen op de arbeidsmarkt. Als er veel vraag is naar het type werkenden bij een bedrijf en daardoor veel werkenden bij het bedrijf vertrekken om elders een beter betaalde baan te krijgen, reageert het bedrijf door de lonen sterker te laten stijgen. Als het daarentegen slecht gaat met het bedrijf, waardoor mensen hun baan kunnen verliezen - en buiten de arbeidsmarkt kunnen raken - is de loongroei juist minder groot. 
De empirische vaststelling dat een hoge loongroei van ouderen samengaat met een lage uitstroom kan verklaard worden doordat het voor oudere werknemers aantrekkelijk is als ze hoge loonstijgingen doormaken ten opzichte van de inkomstenstijgingen bij pensionering of vervroegde uittrede. Een andere verklaring is dat bedrijven die aan oudere werknemers relatief hoge loonstijgingen geven, ook de bedrijven zijn die ouderen graag willen behouden. Dit kan komen doordat deze bedrijven ouderen in dienst hebben met bedrijfsspecifieke kennis en vaardigheden of capaciteiten waarnaar veel vraag is op de arbeidsmarkt.

Het gegeven dat een hoge variantie in de beloning samengaat met een hoge uitstroom kan verklaard worden doordat bedrijven die meer onderscheid in de beloning maken dan het gemiddelde bedrijf, ook vaker medewerkers al dan niet vrijwillig het bedrijf laten uitstromen, bijvoorbeeld volgens het 'up or out' principe. Het gaat om 'dynamische' bedrijven die het belangrijk vinden om een onderscheid tussen medewerkers te maken, waarvoor de transactiekosten bij de uit- en instroom van personeel minder zwaar tellen, en die wellicht minder last hebben van de schaarste aan personeel met specifieke kennis en vaardigheden. Een andere, aanvullende verklaring is dat bedrijven met een meer flexibele beloning medewerkers aantrekken die weliswaar minder risicoavers staan tegenover bijvoorbeeld prestatiebeloning, maar van wie een groot deel na enige tijd weer uitstroomt omdat men toch een lagere productiviteit en beloning heeft dan verwacht.

De resultaten in dit rapport geven geen reden om te verwachten dat de uitstroom van oudere werknemers kan worden beperkt als bedrijven meer variatie in de beloningsstructuur aanbrengen. Niet alleen is er uit de empirische literatuur slechts weinig bewijs beschikbaar dat de productiviteitsontwikkeling van oudere werknemers achterblijft bij hun loonontwikkeling, maar spelen er ook andere factoren een rol die maken dat het eventueel (neerwaarts en flexibel) aanpassen van de beloning aan de productiviteit van ouderen weinig soelaas biedt voor de beperking van de uitstroom van ouderen door bedrijven. Dat betekent dat op basis van de hier uitgevoerde analyses niet verwacht kan worden dat bijvoorbeeld het introduceren van prestatiebeloning op wat grotere schaal door bedrijven zal leiden tot een hogere arbeidsparticipatie van ouderen. De resultaten geven juist aanleiding om rekening te houden met het tegenovergestelde, waardoor de arbeidsparticipatie van ouderen omlaag zou gaan bij het invoeren van meer flexibele beloningssystemen op grotere schaal.

Om de arbeidsparticipatie onder ouderen te verhogen zouden de beleidsacties wellicht ook gericht kunnen zijn op het direct beïnvloeden van de uitstroom, in plaats van uitsluitend via het beloningsbeleid van bedrijven. Interessante vragen voor toekomstig onderzoek zijn dan ook bij welke bedrijven oudere werknemers eerder afvloeien, en of deze bedrijven typische en robuuste kenmerken vertonen wat betreft de sector waarin ze opereren, bedrijfsgrootte, beloningsstructuur, personeelsopbouw, trainingsintensiteit, informeel leren, etc. Juist bij deze bedrijven zouden maatregelen kunnen worden genomen om de arbeidsparticipatie van ouderen te stimuleren. Deze maatre- 
gelen zouden tevens meer gericht kunnen zijn op het aanpassen van de productiviteit aan de beloning (bijv. door formeel en informeel leren) dan andersom.

Ten slotte zou nagegaan kunnen worden wat er gebeurt als bedrijven met grote plotselinge saneringen en personeelsreducties geconfronteerd worden. Veranderen de leeftijdsopbouw en de organisatiestructuur van bedrijven na inkrimpingen en grote reorganisaties doordat veel oudere werknemers afvloeien, en welke mogelijkheden zijn er om binnen de gereorganiseerde bedrijven oudere werknemers te behouden? 


\section{Literatuur}

Aghion P., P. Howitt P. en G. Violante, 2002, 'Generale purpose technologies and within-group inequality', Journal of Economic Growth, Vol. 7, 315-345.

Allen S., 200I, 'Technology and the wage structure', Journal of Labor Economics, Vol. I9, 440-479.

Aubert P., E. Caroli en M. Roger, 2006, 'New Technologies organisation and age', Economic Journal, Vol. II6, 73-92.

Autor D., L. Katz en A. Krueger, 1998, 'Computing inequality: Have computers changed the labor market?’, Quarterly Journal of Economics, Vol. II3, II69-I2I3.

Baker G., M. Gibbs en B. Holmstrom, I994a, 'The Internal Economics of the Firm: Evidence from Personnel Data', Quarterly Journal of Economics, Vol. I09, 88I-919.

Baker G., M. Gibbs en Holmstrom B., I994b, 'The Wage Policy of a Firm', Quarterly Journal of Economics, Vol. I09, 92I-955.

Bayo-Moriones A., J. Galdon-Sanchez en M. Gell, 2004, 'Is seniority-based pay used as a motivation device? Evidence from plant level data', IZA Working paper Nummer I32I, Bonn.

Beweley T., I999, Why wages don't fall during a recession, Harvard University Press, Cambridge, MA.

Blinder A.S., 1982, 'Private pensions and public pensions: Theory and fact', NBER Working Paper 902, Cambridge.

Borghans L. en B. Kriechel, 2006a, Incentive pay and the wage structure of firms: Evidence from a panel of Dutch firms, Conference on the Analysis of Firms and Employees, IAB Nürnberg.

Brüderl J., I99I, Mobilitätsprozesse in Betrieben: Dynamische Modelle und empirische Befunde, Campus Verlag, Frankfurt a.M. 
Cahuc P. en A. Zylberberg, 2004, Labor Economics, Cambridge, MIT Press.

De Grip A. en J. Van Loo, 2002, 'The Economics of Skills Obsolescence: A Review', in Research in Labor Economics Vol 2r: The Economics of Skills Obsolescence: Theoretical innovations and empirical applications', eds: A. de Grip, J. van Loo en K. Mayhew.'

Dohmen T.J., B. Kriechel en G.A. Pfann, 2004, 'Monkey bars and ladders: The importance of lateral and vertical job mobility in internal labor market careers', Journal of Population Economics, Vol. 17, 193-228.

Dostie B., 2006, 'Wages, productivity and aging', IZA discussion paper 2496, Bonn.

Fehr E. en A. Falk, 1999, 'Wage rigidity in a competitive incomplete contract market', Journal of Political Economy, Vol. I07, I06-I34.

Freeman R.B. (2006), Is a great labor shortage coming? Replacement demand in the global economy, National Bureau of Economic Research, NBER Working Paper No. I254I, Cambridge MA.

Gelderblom A., J. De Koning en H. Kroes, 2003, 'Vergrijzing en bedrijfsprestaties', OverWerk, Tijdschrift van het Steunpunt WAV, I47-I5I.

Gielen A.C., M.J.M. Kerkhofs en J. Van Ours, 2006, 'Prestatiebeloning en productiviteit', Economische Statistische Berichten, II augustus, 373-375.

Gitelmans H.M., I966, 'Occupational mobility within the firm', Industrial and Labor Relations Review, Vol. 20, 50-65.

Goldner F.H., 1965, 'Demotions in Industrial Management', American Sociological Review, Vol. 30, 714-724.

Gould E., 2005, 'Inequality and Ability,' Labour Economics, Vol. I2, I69-I89.

Groot W. en M. Verberne, I997, 'Aging, job mobility and compensation', Oxford Economic Papers, Vol. 49, 380-403.

Haley M.R., 2003, 'The Response of Worker Effort to Piece Rates: Evidence from the Midwest Logging Industry,' Journal of Human Resources, Vol. 38, 88I-890.

Hamermesh D., 1993, Labor demand, Princeton, N.J., Princeton University Press.

Hassink W.H.K., 2003, 'Meer oudere werknemers door prikkels aan de vraagzijde?', Economische Statistische Berichten, Vol. 88, I6-I8. 
Hellerstein J.K. en D. Neumark, 1995, 'Are earnings profiles steeper than productivity profiles? Evidence from Israeli data', Journal of Human Resources, Vol. 30, 89-II2.

Hellerstein J.K., D. Neumark en D. Troske, 1999, 'Wages, productivity and worker characteristics: Evidence from plant-level production functions and wage equation', Journal of Labor Economics, Vol. I7, 409-446.

Hutchens R., 1987, 'A test of Lazears theory of delayed payment contracts', Journal of Labor Economics, Vol. 5, I53-I70.

Johnson R.W., I996, 'The Impact of human capital investments on pension benefits', Journal of Labor Economics, Vol. I4, 520-554.

Katz L. en K. Murphy, 1992, Changes in relative wages, 1963-1987: 'Supply and Demand Factors', Quarterly Journal of Economics, Vol. I07, 35-78

Kotlikoff L.J. en J. Gokhale, I992, 'Estimating a firm's age-productivity profile using the present value of workers' earnings', Quarterly Journal of Economics, Vol. I07, I215I242.

Lazear E., 1979, 'Why is there mandatory retirement', Journal of Political Economy, Vol. 87, I26I-I284.

Lazear E.P., 1986, 'Salaries and Piece Rates', Journal of Business, Vol. 59, 405-431.

Lazear E.P., 1992, 'The Job as a Concept' In: Bruns, W. (ed) Performance Evaluation and Incentives, Harvard Business School Press, Boston.

Lazear E.P., 2000, 'Performance pay and productivity', American Economic Review, Vol. 90, I346-I36I.

Lazear E. en R. Moore, 1984, 'Incentives, productivity and labor contracts', Quarterly Journal of Economics, Vol. 99, 275-295.

Lima F. en P.T. Pereira, 2003, 'Careers and wages within large firms: evidence from a matched employer-employee data set', International Journal of Manpower, Vol. 24, $8 \mathrm{I} 2-835$.

Medoff J.L. en K.G. Abraham, I98I, 'Are those paid more really more productive? The case of experience', Journal of Human Resources, Vol. 16, 186-216.

Montizaan R.M., F. Cörvers en A. de Grip, 2007, Training and early Retirement, ROARM-2007/3, Maastricht. 
Neumark D. en P. Taubman, 1995, 'Why do wage profiles slope upward? Test of the general human capital model', Journal of Labor Economics, Vol. 13, 736-761.

Oster S. en D. Hamermesh, 1998, 'Aging and productivity among economists', Review of Economics and Statistics, Vol. 80, I54-I56.

RWI, 2004, Vergrijzing en vervanging, Een analyse van de gevolgen van het uitstromen van de babyboomgeneratie voor de arbeidsmarkt, Raad voor Werk en Inkomen, I november, Den Haag.

Paarsch, H. en B. Shearer, 1999, ,The Response of Worker Effort to Piece Rates: Evidence from the British Columbia Tree Planting Industry', Journal of Human Resources, Vol. 34, 643-667.

Paarsch, H. en B. Shearer, 200o, 'Piece Rates, Fixed Wages, and Incentive Effects: Statistical Evidence from Payroll Records', International Economic Review, Vol. 4I, 59-92.

Prendergast C., 1999, 'The provision of incentives in firms', Journal of Economic Literature, Vol. 37, 7-63.

Rosenbaum, J.E., 1984, Career Mobility in a Corporate Hierarchy, Academic Press, Orlando.

Salop S. en J. Salop, 1976, 'Self selection and turnover in the labor market', Quarterly Journal of Economics, Vol. I, I63-84.

SCP, 2004, In het zicht van de toekomst: Sociaal en Cultureel Rapport 2004, Sociaal Cultureel Planbureau, Den Haag.

Song, X., 2005, The effects of technological change on schooling and training human capital, Working Paper.

SZW, 2005, Voorjaarsrapportage CAO-afspraken 2005, Ministerie van Sociale Zaken en Werkgelegenheid, Den Haag.

Topel, R., I99I, 'Specific capital, mobility and wages: Wage rises with job seniority', Journal of Political Economy, Vol. 99, I45-176.

Treble, J., Barmby, T., S. Bridges en E. Van Gameren, 200I, 'The internal economics of the firm: further evidence from personnel data', Labour Economics, Vol. 8, 53I-552. 
Tuma, N., 1985, 'Effects of labor market structure on job-shift patterns'. In: J. Heckmann and B. Singer (eds.), Longitudinal analysis of labor market data, 327-363, Cambridge: Cambridge University Press.

Van Loo, J., A. de Grip en R. Montizaan, 2005, Active aging bij overheid en onderwijs: Vernieuwend omgaan met vergrijzing, ABP belevingsonderzoek, Maastricht.

White R.P. en R.P. Althauser, 1984, 'Internal Labor Markets, promotions and worker skill: an indirect test of skill ILMs', Social Science Research, Vol. 13, 373-392.

Zeckhauser R., 1968, 'Optimality in a world of progress and learning', Review of Economic Studies, Vol.35, 363-365. 



\section{Bijlage A}

De figuren A.I tot 4.4 laten zien wat de verschillen in kenmerken van de beloningsstructuur inhouden. Iedere figuur geeft een gestileerde weergave van de loonsveranderingen, met donkere lijnen voor de gemiddelde loongroei, en lichte lijnen voor een standaarddeviatie boven en onder dit gemiddelde. Het gaat telkens om een simulatie van de loonsveranderingen voor een bedrijf van 200 medewerkers.

\section{Figuur A.1}

Gestileerde weergave en simulatie van de loonsveranderingen bij een bedrijf met de drie parameters gelijk aan de mediaan

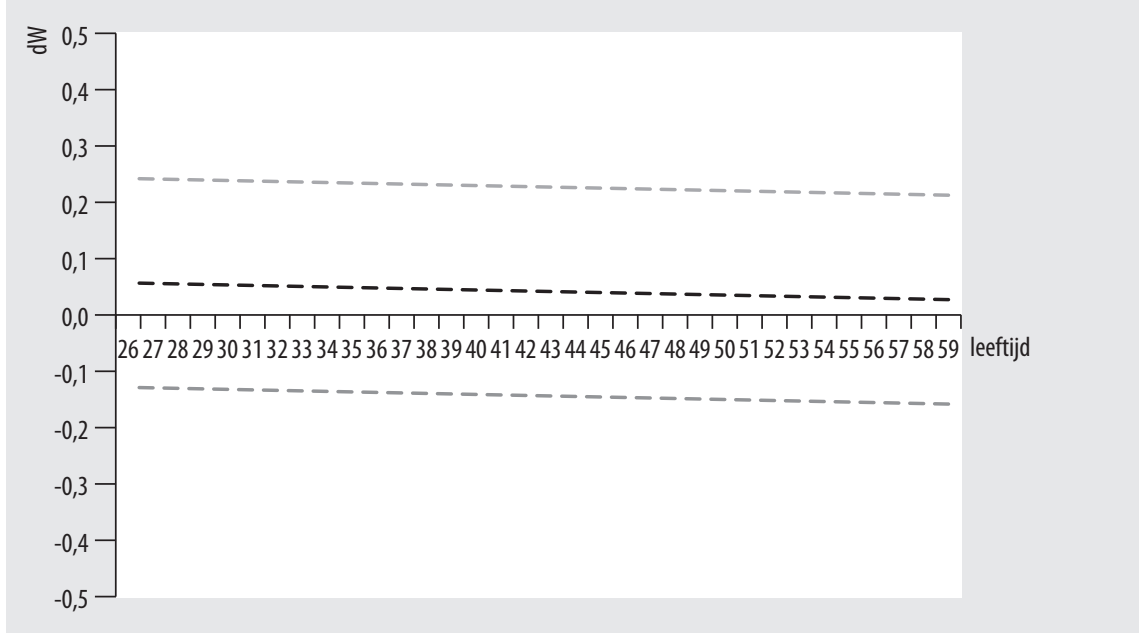

Figuur A.I geeft de loonsveranderingen weer voor een bedrijf met parameters die gelijk zijn aan de mediaan. Bij figuur A.2 zijn twee bedrijven weergegeven. Bij het ene bedrijf (doorlopende lijnen) is de parameter $a$ gelijk aan het Io-de percentiel, en bij het andere bedrijf (stippellijnen) is deze parameter gelijk aan het 90-ste percentiel. De andere twee parameters blijven gelijk aan de mediaan. Bij figuur A.3 wordt op vergelijkbare wijze het verschil in de parameter $b$ tussen het Io-de en 90-ste percentiel getoond. Figuur A.4 laat dit voor de standaarddeviatie zien. 


\section{Figuur A.2}

Gestileerde weergave en simulatie van de loonsveranderingen bij twee bedrijven met de parameter $a$ gelijk aan het 10-de (doorlopende lijnen) en 9o-ste (onderbroken lijnen) percentiel en de twee overige parameters gelijk aan de mediaan

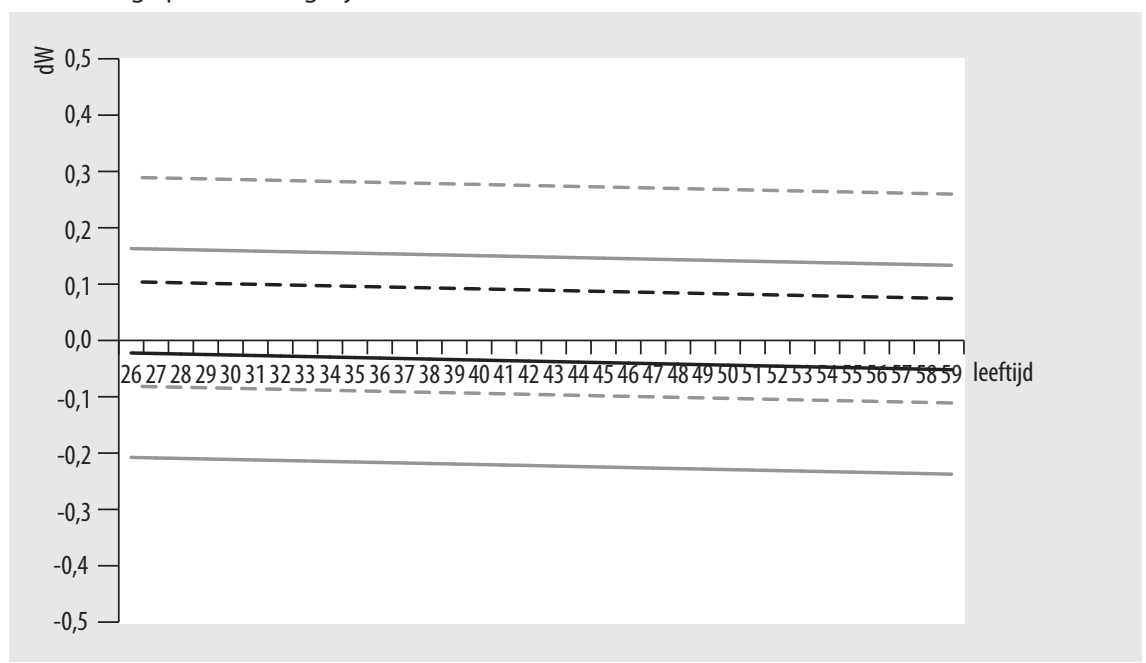

\section{Figuur A.3}

Gestileerde weergave en simulatie van de loonsveranderingen bij twee bedrijven met de parameter $b$ gelijk aan het 10-de (doorlopende lijnen) en 9o-ste (onderbroken lijnen) percentiel en de twee overige parameters gelijk aan de mediaan

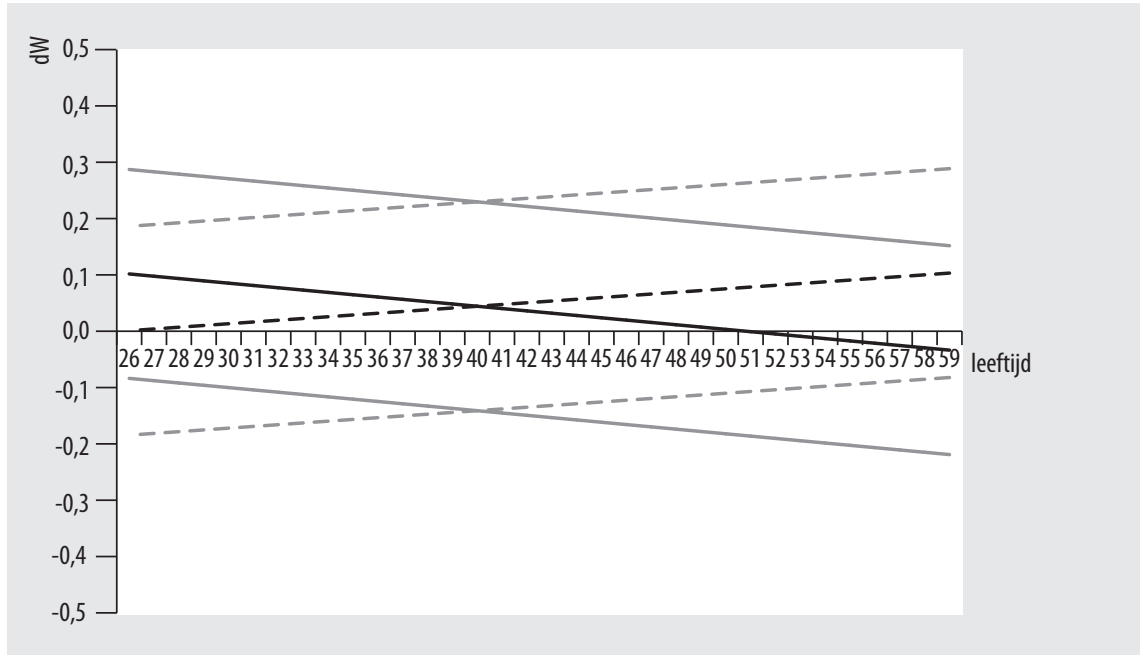




\section{Figuur A.4}

Gestileerde weergave en simulatie van de loonsveranderingen bij twee bedrijven met de parameter sd gelijk aan het 10-de (doorlopende lijnen) en 9o-ste (onderbroken lijnen) percentiel en de twee overige parameters gelijk aan de mediaan

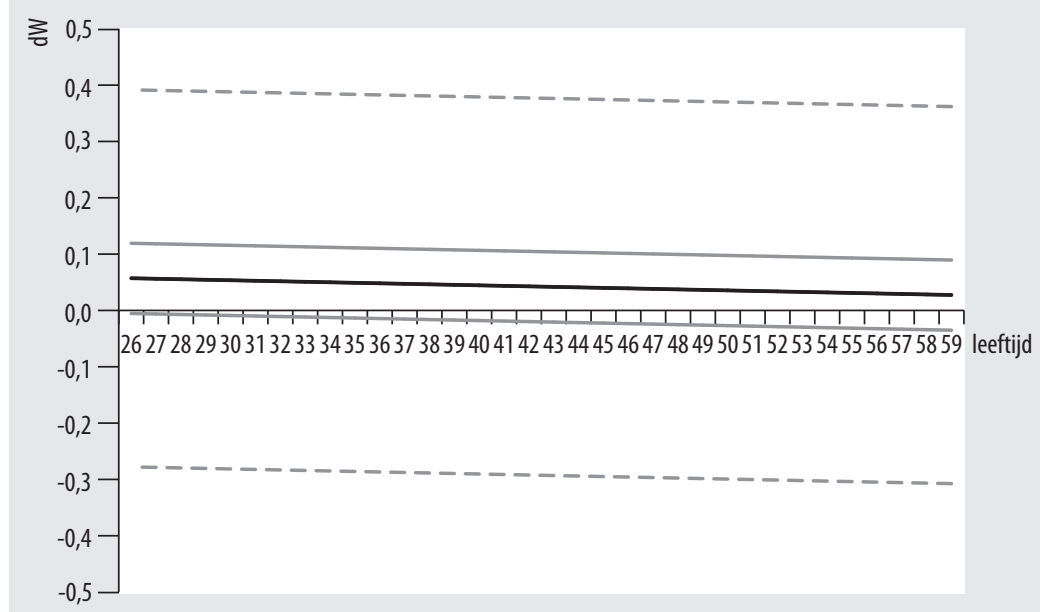


